\title{
PASARGĀ NO VISA JAUNA JEB LATVIEŠU TËVREIZE SEBASTIĀNA MINSTERA KOSMOGRĀFIJAS IZDEVUMOS
}

\author{
Ernesta KAZAKĖNAITÉ \\ Vilı,nas Universitāte
}

\section{Ievads}

16. gs. tēvreizes bija populārs valodu paraugs vai to salīdzināšanas veids pasaules aprakstos. Tā pirms 470 gadiem radies senākais zināmais iespiestais teksts latviešu valodā - tā saucamā Hāzentētera tēvreize. Kaut gan plaši zināms un bieži pieminēts fakts ${ }^{1}$, ka pirmā drukātā latviešu tēvreize atrodama Sebastiāna Minstera 1550. g. kosmogrāfijā (turpmāk - MK) gan vācu valodā², gan tai pašā gadā izdotajā tulkojumā latīṇu valodāª , par pārējiem šīs grāmatas izdevumiem, kam patiesībā ir nosacīi liela dažādība, reti plašāk runāts. Taču digitālo resursu laikmetā ir radusies iespēja vienuviet salīdzināt zināmos latviešu tēvreizes publicējumus kosmogrāfijas atkārtotos izdevumos. Līdz ar to tas ir kḷuvis par šā raksta mērḳi - sniegt ieskatu par latviešu tēvreizes publicējumiem Minstera kosmogrāfijas izdevumos, uzmanību pievēršot to atkalizmantošanas virzieniem un pieraksta daudzveidībai, kā arī aktualizēt vairāku MK tēvreizes pieraksta tradīciju esamību.

Ieskats sastāv no trijām dalāam un pielikuma. Pirmajā dạ̣ā (2.) vispārīgi aplūkoti MK atkārtotie izdevumi, otrajā (3.) - latviešu tēvreizes publicējumi MK četrās valodās, bet trešajā (4.) - teksta atkalizmantošanas virzieni. Raksta pielikumā atrodams paralēlais pētìto tēvreižu korpuss. Pieņemot, ka sakari starp tēvreizēm atsevišksās grāmatās vislabāk atspogulojojas, identificējot kopīgās pārējos avotos neatrodamās korekcijas, tālāk skatītas tikai tās, neatkārtojot pielikumā sniegto pilno tēvreizes pārrakstu.

\section{S. Minstera kosmogrāfijas izdevumi}

Nav šaubu, ka Minstera ${ }^{4}$ kosmogrāfija ir viens no slavenākajiem enciklopēdiska satura 16. gs. izdevumiem. Nācis klajā 1544. g., tas uzreiz guva

1 Sk. Meringer 1895; Arbuzovs 1920; Augstkalns 1930; Hinze 1976; Pokrotniece 2012 utt.

2 Münster, Sebastian 1550. Cosmographei || oder beschreibung aller lån/||der/ herschafften/ fürnemsten || stetten/geschichten/gebreūchēe/ hantierungen etc. <...>. Basel: Petri.

3 Münster, Sebastian 1550. COSMO||GRAPHIAE || uniuersalis Lib.VI. in || quibus, iuxta certioris fidei scriptorum || traditionem describuntur <...>. Basileae: Heinrich Petri.

4 Sebastiāns Minsters (vācu Sebastian Münster) dzimis 1488. g. 20. janvārī Lejasingelheimā, miris 1552. g. 26. maijā Bāzelē (Priesner 1997: 539; Wessel 2004: 21). 
ievērību un ne vien tā iespaidīgā kokgriezumu zīmējumu skaita dẹ̣̄. ${ }^{5}$ Taču jāsaka, ka tas nav bijis nemainīgs izdevums - tika tulkots vairākās valodās un 84 gadu laikā ${ }^{6}$ ar dažāda apjoma izmaiņām atkārtoti izdots vairāk nekā 30 reižu. Tomēr nedz ārzemju, nedz latviešu pētnieku darbos nav vienprātības, cik reižu Minstera kosmogrāfija tikusi izdota. Viens no senākajiem viedokḷiem ir tāds, ka darbs izdots 46 reizes (Hantzsch 1898: 28; līdzīgi Hodgen 1954: 507), taču šo uzskatu nav atbalstījuši citi zinātnieki, kas lielākoties uzskatījuši, ka 35 reizes (Ruland 1962; Freidhof 1988: XVIII; McLean 2007: 1; Dini 2010: 258 utt.). ${ }^{7}$ Apkopojot atsevišksu autoru izteikumus ${ }^{8}$ un apvienojot tos ar vācu bibliogrāfiju (VD16; VD17) dotumiem, kā arī apskatītajiem digitālajiem eksemplāriem, laikam jādomā, ka bijuši vismaz šādi 37 pilnīgi izdevumi piecās valodās:

- vācu (21): 1544, 1545, 1546, 1548, 1550, 1553, 1556, 1558, 1561, $1564,1567,1569,1572,1574,1578,1588,1592,1598,1614 a, 1614 b$ (dažviet 1615), 1628 ;

- latīnu (6): 1550, 1552a, 1552b的, 1554, 1559, 1572;

- franču (6): 1552, 1556, 1560, 1565, 1568, 1575 (jaunā tulkojumā);

- čehu: 1554;

- itālu (3): 1558, starp 1558 un 1571, 1575.

Gandrīz visi izdoti Bāzelē Heinriha Petri spiestuvē, izņemot četrus, jo 1554. g. MK čehu valodā izdota Prāgā, 1575. g. franču MK - Parīzē, bet divi pēdējie itāḷu MK izdevumi attiecīgi Venēcijā un Ķelnē.

${ }^{5}$ Pirmajā MK izdevumā bija vairāk nekā 600 lappušu un tajās esot 520 kokgriezumu (Galić, Došen 2017: 77).

${ }^{6}$ Viedokḷi dalās (sal. Hantzsch 1898: 28), tomēr mūsdienās par pēdējo tiek uzskatīts 1628. g. izdevums.

7 Lai gan sniegtais skaits - 35 - sakrīt, ne jau visi tajā ir iekḷāvuši tos pašus izdevumus; daži nav ieskaitījuši čehu, daži 1614. g. vācu otro izdevumu.

8 Jāpiebilst, ka viedokḷ dažādība ir pat lielāka, nekā pieminēta tekstā, sk., piem., Švābe 1936: 40; Horn 1950: 70; Ozols 1965: 58; Burmeister 1969; Meurer 1993: 20; van Putten 2017: 1; Klekere 2020: 114 utt.

9 Jāteic, ka pētījuma gatavošanas laikā neizdevās nonākt līdz pilnīgai skaidrībai par 1614. g. (cik to bija) un 1615. g. (vai bija) vācu MK izdevumiem. Tomēr, balstoties uz VD17 un Rulanda (1962) secinājumiem, jādomā, ka, kaut pasūtītajā Freiburgas Alberta-Ludviga Universitātes bibliotēkas kopijā (sign. J 4763,ti) skaidri var redzēt, ka titullapā izdrukāts M. DC. XV. un tam ir nedaudz atšķirīgs nosaukums - Cosmographia, Das ist Außführliche vnd eigentliche beschreibung aller Ländern, Herrschafften vnd fürnembsten Stätten der gantzen Welt $<\ldots>$, tas ir 1614. g. laidiena izdevums ar otro titullapu (vairāk Ruland 1962).

${ }^{10}$ Neviens no citētajiem autoriem nav iekḷāvis $\mathrm{MK}_{\text {lat }} 1552 \mathrm{~b}$ izdevumu (par to tālāk 3.2. apakšnodalāa). 
Par galveno izdevumu uzskatāms nevis pirmais, bet ievērojami papildinātais 1550. g. izdevums ${ }^{11}$ (Lindgren 2002: 34). Tas bijis arī pēdējais paša Minstera stipri redig̣êts izdevums, un tieši tajā pirmo reizi atrodama latviešu tēvreize. ${ }^{12} \breve{S}_{1}$ gada laidienā balstījušies vēlākie tulkojumi: pirmais - latīṇu valodā - publicēts vēl tai pašā 1550. g., tam sekoja franču (1552. g.), angḷu (1553. g.) $)^{13}$, čehu (1554. g.) un itāḷu (1558. g.). Tulkojums angḷu valodā bieži vien netiek iekḷauts Minstera kosmogrāfijas tulkojumu sarakstā (sk. arī iepriekš), jo tulkotājs Ričards Edens (Richard Eden) no latīṇu valodas iztulkojis tikai dažas sensacionālākās grāmatas dalias un izdevis ar citu nosaukumu ${ }^{14}$. To vidū ne Livonijas apraksta, ne latviešu tēvreizes nav (Robinson, Leyland 1964: 70). Lai gan sadaļa par Livoniju atrodama visos vēlākajos minētajos izdevumos, tieši pētāmās tēvreizes nav arī kosmogrāiijā čehu valodā. Tātad, neskaitot minētos un pirmos četrus vācu 1544.-1548. g. izdevumus, jāsecina, ka latviešu tēvreize atrodama vismaz $32 \mathrm{MK}$ izdevumos ar tulkojumu četrās valodās (vācu, latīṇu, franču un itālù). Ar daudzu bibliotekāru atbalstu š̄̄ pētījuma gatavošanas laikā visi minētie $32 \mathrm{MK}$ izdevumi vai to fragmenti bija pieejami. ${ }^{15}$ Taču jâuzsver, ka apskatīta tikai daḷa attiecīgā izdevuma eksemplāru (sk. avotu sarakstā). Tāpēc pastāv iespēja, ka citās bibliotēkās glabātajos izdevumos būtu atrodamas kādas atšķirības.

\section{Latviešu tēvreize S. Minstera kosmogrāfijā}

Par MK latviešu tēvreizi un vēl vairāk par pašu Livonijas aprakstu dažādu nozaru pētnieki ir rakstījuši daudz un izsmeļoši ${ }^{16}$. Laikam par visapjomīgāko darbu filologa skatịjumā būtu jāsauc Kārla Draviņa publikācija (1952), kurā viņš aplūkojis pierakstus pirmajos izdevumos un izvirzīị svarīgas hipotēzes par iespējamiem tēvreizes avotiem. Neatkārtojoties pārāk

${ }^{11}$ Nav skaidrības, vācu vai latīṇu MK izdota pirmā, jo abu priekšvārdi parakstīti martā — vācu izdevumā precizēts (17. martā; am xvij. tag des Mertzen), bet latīṇu atstāts tikai mēneša nosaukums (M.D.L. mense Martio).

12 Par pašu pēdējo Minstera sagatavoto izdevumu uzskatāms tulkojums franču valodā, ko autors parakstīijis 1552. g. maijā.

13 Jāpiemin, ka bijuši arī citi vēlāki dal̦ēji angḷu tulkojumi, piem., 1561. g. Džordža Norta (George North) The Description of Swedland, Gotland and Finland $\langle\ldots\rangle$, kura sastādīšanā lielākoties izmantota Minstera kosmogrāfija.

${ }^{14}$ A treatyse of the newe India with other new founde landes and islandes, aswell eastwarde as westwarde, as they are knowen and found in these oure dayes $<\ldots>$. London: Edward Sutton.

${ }_{15}$ Lielākā daḷa kosmogrāfiju ir brīvi pieejamas internetā (sk. avotu sarakstā), trūkstošie retie eksemplāri bija pasūtīti sadarbībā ar atsevišksu bibliotēku darbiniekiem.

16 Sk. Schirren 1858; Meringer 1895; Arbuzovs 1920; Švābe 1936; Draviņš 1952; Klekere 2020 utt. 
daudz, jāpiezīmē - tiek uzskatīts, ka tēvreize pierakstīta ne vēlāk kā 1547. g. (Arbuzovs 1920: 358; Draviņš 1952: 220) Rīgā (Draviņš 1972: 26), bet tās pierakstītāis, kā zem tēvreizes norādīịis pats Minsters 1550. g. izdevumā (932. lpp.), ir Johans Hāzentēters ${ }^{17}$ :

Dis alles oder züm groffern theil hab ich võ dem weit erfarn Johan Hafentódter || fo manch jar in Lyffland an den herren höffen vnd Cãtzeliẽ gewefen / vil erfarẽ hat.

Tomēr arvien atklāts jautājums, kur Hāzentēters dabūjis šo tēvreizi, — vai pats pierakstīịis dzirdēto (Meringer 1895: 499), vai norakstīịis no rakstītā. Pie pēdējās hipotēzes nonācis Draviņš (1952: 227), kurš hipotētiski min, ka Hāzentēters tēvreizi norakstījis no kādas grāmatas, kurā latviešu teksts iespiests fraktūrā. ${ }^{18}$ Tomēr to pamatot ir grūti, jo, pirmkārt, vismaz pašlaik tāda grāmata nav zināma, otrkārt, tēvreizes teksts stipri atšşiras no pirmajā luterāṇu latviešu katķismā atrodamā, kas saglabājis Rīgas tradīciju (sal. Vanags 1996).

Tā kā 1550. g. MK izdevumi vācu un latīṇu valodā iznāca gandrīz vienlaikus, cits atklāts jautājums, kas savulaik bija apspriests literatūrā, - kādu un kādā valodā rakstītu tekstu Hāzentēters ir nodevis tālāk Minsteram. Šeit Draviņš (1952: 225), balstīdamies rakstībā, piedāvā hipotēzi, ka Minsters to saņēmis gotiskajā šriftā, proti, vācu valodā, un ļoti maz ticams, ka tai līdzās būtu bijis tas pats apraksts, tikai latīṇu valodā. Tomēr par tuvāko sākuma tekstam uzskata MK latīnu valodā esošo pierakstu (Draviņš 1952: 221).

Rets pētijums, kurā plašāk pieminēta 1550. g. tēvreize, paiet garām valodas analīzei. Tāpēc pastāv arī dažādi uzskati par šīs tēvreizes vecumu un pareizumu jeb atbilstību iespējamam tai laikā pastāvējušam variantam, kuru pat mēg̣ināts rekonstruēt (Meringer 1895: 495; Draviņš 1952: 221). Tomēr šai rakstā par vecākās iespiestās tēvreizes valodu netiks runāts, bet uzmanība pievērsta tās izplatîbai un laika gaitā tapušiem variantiem MK izdevumos vācu (3.1.), latīṇu (3.2.), franču (3.3.) un itālu (3.4.) valodā. Arī par to vietumis ir rakstīts agrāk, taču fragmentāri, un līdz šim tikai dą̧a $M K$ izdevumu ${ }^{19}$ aplūkoti vienuviet.

\subsection{Tēvreizes Minstera kosmogrāfijas izdevumos vācu valodā $\left(\mathrm{MK}_{\mathrm{v}}\right)$}

Līdztekus Livonijas aprakstam Minstera kosmogrāfijā vācu valodā latviešu tēvreize atrodama pat 17 izdevumos, t. i., kopš piektā $\mathrm{MK}_{\mathrm{v}}$ jeb visos, kas

17 Vācu Johann Hasentödter, dzejnieks un hronists, dzimis 1517. g. Kēnigsbergā, miris 1586. g. Dancigā, vairāk sk. Günther 1913.

18 Pie šìs hipotēzes autors arī palicis, sal. Draviņš 1972: 26.

${ }^{19}$ Lielākais skaits vienuviet aplūkotu MK latviešu tēvreižu ir sešas, tās atrodamas Dini 2010: 522-524) pētījumā. 
klajā laisti pēc 1550. g. (sk. 1.-17. tēvreizi pielikumā). Interesanti, ka tikai viens (nākamais) piln̄̄gi atbilst pirmajam latviešu tēvreizes publicējumam, pārējos, kaut vai sīkas, tomēr vērojamas atškirīibas. Izmantojot digitālo rīku Lexos $^{20}$, sakarus starp visiem 17 publicējumiem var atspogulot tālāk sniegtajā dendrogrammā. Tā rāda, ka diezgan hronolog̣iski būtu jāškịir divas lielas $\mathrm{MK}_{\mathrm{v}}$ grupas - pirmie 1550.-1592. g. un vēlākie 1598.-1628. g. izdevumi - ar daudzām apakšgrupām:

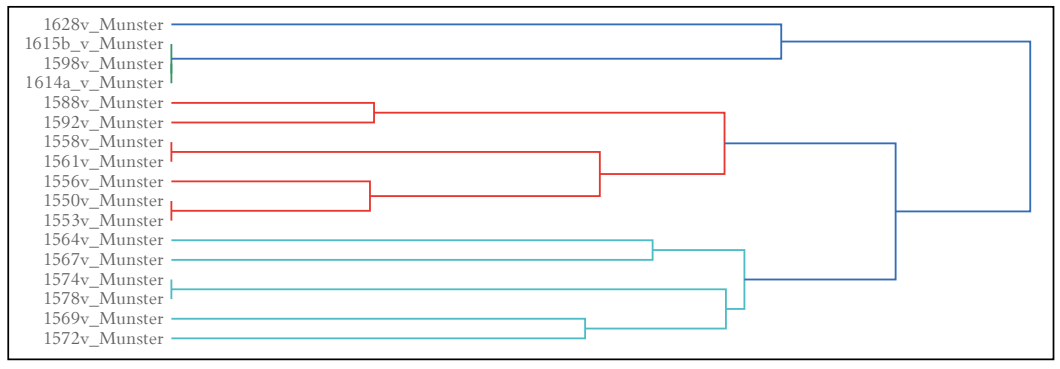

Dendrogramma. Latviešu tēvreizes sakari $\mathbf{M K}_{\mathrm{v}}$ izdevumos

Dendrogrammā redzams ne tikai tas, kā tēvreizes ziņā grupējas atsevišķi izdevumi, bet arī - kuri no tiem ir identiski (tos vieno vertikālā līnija kreisajā pusē). Tātad ar pirmo publicējumu (1550. g.) pilnīgi sakrīt tikai nākamais (1553. g.) izdevums, taču jau kopš trešã (1556. g.) vērojamas atškikirības. Tomēr 1556. g. izdevums no pirmajiem atšksiras tikai ar vienu vienīgo pazīmi - důth vietā rakstīts düth. Šāda dot rakstība atkārtota ne vien nākamajā, 1558. g., un tam identā 1561. g. izdevumā, bet paturēta vācu MK gandrīz līdz gadsimta beigām (sk. 27. vārdu pielikumā). Ceturtais un tam identais piektais $\mathrm{MK}_{\mathrm{v}}$ izdevums, kas satur latviešu tēvreizi, no iepriekšējiem atškiras arī ar burta rakstību vienā konkrētā vārdā, turklāt šĩ atšşirīiba novērojama divreiz - muße vietā ir muffe. Jāpiebilst, ka pāreja no $\beta$ uz ff nav konsekventa, jo $\beta$ vēl atstāts pat līdzīgos vārdos, tiesa, vārda beigās - müm $\beta$ un me $\beta$.

Pirmajos piecos iepriekš minētajos $M_{\mathrm{v}}$ izdevumos atškirīibas latviešu tēvreizes rakstībā ir ļoti sīkas, taču ar sesto (1564. g.) ienāk lielākas, un dažas ir skaidras korektūras kḷūdas, kas laika gaitā vēl vairojušās. Ar 1564. g. grāmatu latviešu tēvreizes publicējumos ienāk ka eckfchkan vietā kaeckfchkan ${ }^{21}$, fchodeen $\rightarrow$ fchoden, parradueken $\rightarrow$ parraduekẽ, paffarga $\rightarrow$ pafferga. Arī loune

\footnotetext{
20 http://lexos.wheatoncollege.edu/

${ }^{21}$ Patiesībā par atstarpi starp šiem vārdiem ir ḷoti grūti spriest.
} 
vietā ir loune. (ar punktu), jo pazūd un nevienā vēlākajā vācu izdevumā netiek iekḷauts apstiprinājums Amen lūgšanas beigās. Skatoties teksta salikumā, škiet, ka šì noslēguma atmešanas cēlonis varēja būt praktisks - ierasto piecrindu lūgšanu, kas atrodama 1550.-1561. g. izdevumos, ietilpinot četrās rindās, beigu vārdam vietas vairs nav pieticis.

Nākamais (1567. g.) tēvreizes izdevums ne vien atkārto minētās 1564. g. izdevuma îpatnības, bet vēl vairāk attālinās no sākotnējā varianta, jo tows vietā ir tous, waartz $\rightarrow$ wartz, praats $\rightarrow$ prauts, parradueke $\rightarrow$ parreduekẽ, bet vēlākajā 1569. g. izdevumā vēl debbeffis vietā ir debeffis, walftibe $\rightarrow$ walftibe/ un Debbes/ $\rightarrow$ Debbes (interpunkcija), femmes $\rightarrow$ fer̃es, me $\beta \rightarrow$ mes, mums $\rightarrow$ $m \bar{u} s$. Šim, astotajam, $\mathrm{MK}_{\mathrm{v}}$ izdevuma pierakstam diezgan līdzīgs ir esošais devītajā (1572. g.) laidienā, kurš no iepriekšējā atškiriras ar trim pazīmēm: kaeckfchkan $\rightarrow$ kaeekfchan, fchoden $\rightarrow$ fchodẽ, parreduekẽ $\rightarrow$ parrednekẽ. Vēlākajā 1574. g. un tam identajā 1578. g. izdevumā dažas iepriekšējo publicējumu īpatnības un iespējamās korektūras kḷūdas palabotas: kaeekfchan $\rightarrow$ kaeckfchkan, feñes $\rightarrow$ femmes, müm $\beta \rightarrow$ mum $\beta$, ka mes $\rightarrow$ kames, parrednekẽ $\rightarrow$ parreduekẽ, mũs $\rightarrow$ mums. Vērtējot kopīgās īpatnības, kas lielākoties jāuzskata par korektūras kḷūāam (kā prauts, pafferga), jāsecina, ka 1564.-1578. g. MK $_{\mathrm{v}}$, t. i., 6.-11. izdevums, veido atsevišksu $\mathrm{MK}_{\mathrm{v}}$ pirmās grupas apakšgrupu (sk. arī dendrogrammā). Interesanti, ka secinājums sakrīt ar Ināras Klekeres (2020: 118) uzsvērto, ka tieši šajos izdevumos notikusi atteikšanās no Livonijas apraksta ilustrācijām, atstājot vienīgi autentisko Rīgas panorāmu. ${ }^{22}$

Jauna ievirze $M K_{v}$ latviešu tēvreizes publicējumos, vienlaikus arī apraksta ilustrēšanā ${ }^{23}$, ienāk ar 1588. g. laidienu, kas bija pirmā pēc iespiedēja Heinriha Petri nāves izdotā MK. Patiesībā jauninājumi vērojami ne vien latviešu tēvreizes pierakstā, bet arī visā izdevumā, piem., pētot MK kartes, Meirers (Meurer 1993) secinājis, ka tieši 1588. g. izdevumā tās ir modificētas. Arī tajā esošajā tēvreizē kopš 1564. g. MK $\mathrm{v}_{\mathrm{v}}$ izdevumiem raksturīgās īpatnības lielākoties netiek atkārtotas, iznnemot dažas ar interpunkciju saistītas vietas, t. i., walftibe $\rightarrow$ walftibe/ un Debbes/ $\rightarrow$ Debbes, kā arī loune vietā ir loune., kur punkts aiz vārda radies, atmetot Amen. Tas rāda, ka 1588. g. izdevums netika pārrakstīts no kāda agrāka, vēl pirms 1564. g. izdota avota, taču labots, tos salīdzinot. Tādēḷ tajā nav atrodami nedz prauts, nedz pafferga, nedz citi tipiski kḷūdaini vārdu salikumi. Taču, ar kuru tieši salīdzināts 1588. g. izdevums, grūti spriest. Iespējams, tas bijis 1558. g. vai idents 1561. g. izdevums, jo no vēl agrākiem atškiriras ar muffe rakstišanu - tajos ir muße. No pilnīgi visiem

22 Jāpiebilst, ka autore min trīs no MK izdevumiem, tomēr patiesībā atteikšanās ir visos apakšgrupā iekḷautajos (1564. g., 1567. g., 1569. g., 1572. g., 1574. g. un 1578. g. izdevumā).

${ }^{23}$ Pievienoti pieci jauni saturiski derīgi attēli, vairāk sk. Klekere (2020: 118-120). 
iepriekšēiiem izdevumiem 1588. g. $\mathrm{MK}_{\mathrm{v}}$ izdevums atškiras tikai ar divām paz̄imēm: mum $\beta$ vietā ir mums, bet můms $\rightarrow$ mums. Tās ir paturētas gandrīz identā nākamajā (1592. g.) izdevumā, kurš no iepriekšèjā atškiras vienīgi ar to, ka düth vietā ir düth.

Visinteresantākais no pētāmajām $\mathrm{MK}_{\mathrm{v}}$ ir to pēdējais 16. gs. izdevums, tas arī visvairāk atş̌kiras un kopā ar vēlākajām $M_{\mathrm{v}}$ veido atsevišḳku lielu grupu (sk. dendrogrammā). Škikiet, kaut 1598. g. izdotā kosmogrāfija vācu valodā lielākoties balstās uz iepriekšējiem vācu izdevumiem, lūgšana grūti iedomājamu iemeslu dēl rediḡeta pēc kāda franču varianta (sal. 14. un, piem., 28. tēvreizi pielikumā). Tomēr interesanti, ka tā piln̄ibā neatbilst nevienam pētītam pierakstam, bet ir kāds kontaminējums. Lai gan nav pārṇemta visiem franču izdevumiem raksturīgā vārdu secība tēvreizes uzrunā (mus tabes), pārējās būtiskās franču izdevumu īpatnības ir atkārtotas (sk. 3.3.), t. i.: pammat vietā atrodams pammart, arī daḷēji sakrīit citas „franciskas“ kḹùdas - ka ekfchkan vietā ir eka ekfchkan (franču - eka kfchkan), louna vietā jouna, arī vārda prāts rakstība praatz, nevis praats, kā agrākajās $\mathrm{MK}_{\mathrm{v}}$. No iepriekšējiem vācu izdevumiem 1598. g. tēvreize vēl atškiras ar eckfchan $\rightarrow$ eckfchkan, $N e$ wedde $\rightarrow$ Ne ewedde, düth $\rightarrow$ duth, wüffe $\rightarrow$ wuffe, tomēr šo korekciju avots nav tik viegli identificējams, jo tās atrodamas jau pirmajos latīṇu (sk. 3.2.) un itāḷu tulkojumos. Taču, tā kā visas ir arī pieminētajos franču izdevumos, visticamāk, tas nāk no franču teksta kopā ar tikai tam variantam raksturīgajām korekcijām. Lai gan fakts, ka tēvreizes pierakstu atkārtotā kosmogrāfijas vācu izdevumā varējis ietekmēt kāds franču avots, pārsteidz, vispār tāda informācijas ceḷošana starp MK izdevumiem novērojama (Mclean 2005: 241). Tomēr nav iespējams precīzāk noteikt, kurš tieši izdevums ir pamatā šìm korekcijām un vai tiešām tas bijis kāds no pētītajiem, vai tās ienākušas ar kāda vēl nezināma avota starpniecību, kas uzskatīts par autoritatīvāku. ${ }^{24}$

Šķiet, 17. gs. iznākuši trīs $\mathrm{MK}_{\mathrm{v}}$ izdevumi: 1614a, 1614b un 1628. Visos publicêtā latviešu tēvreize ir ḷoti līdzīga atrodamajai iepriekš minētajā 1598. g. izdevumā. Abi 1614. g. izdevumi ir identi un, lai gan ir jaunā salikumā (daži vārdi rakstīti ciešāk), sakrīt ar iepriekšējo izdevumu (sal. 14., 15. un 16. tēvreizi pielikumā). Nedaudz vairāk no agrākajiem atškiras pēdējais (1628. g.) MK izdevums vācu valodā (sk. arī 1. attēlu). Tajā ne vien atkārtotas visas ar 1598. g. izdevumu ienākušās ,franciskās“ iezīmes, bet papildus tām radušās arī acìmredzamas lasīšanas kḷ̂ùdas. T. i., divreiz 1614. g. izdevumos ḷ̣ti

24 1598. g. MK $_{\mathrm{v}}$ teksts salīdzināts arī ar citiem zināmiem franču tradīcijas latviešu tekstiem, kuri izdoti pirms tā, kā Andrē Tevē (1575) vai Hieronīma Megisera (1593) darbiem, tomēr nekādas acīmredzamas sakritības ar konkrētu publicējumu netika pamanītas. 
tuvu iespiesti vārdi 1628. g. interpretēti kā viens - eckfchkan debbeffis $\rightarrow$ eckfchkandebbeffis un eckfchkan Debbes $\rightarrow$ eckfchkannDebbes ${ }^{25}$, bet vienreiz $r$ burts, kas visos iepriekšejos vācu izdevumos salikts citā šriftā (rotundā), pārvērties par $z$ - parradueken $\rightarrow$ parzadueken.

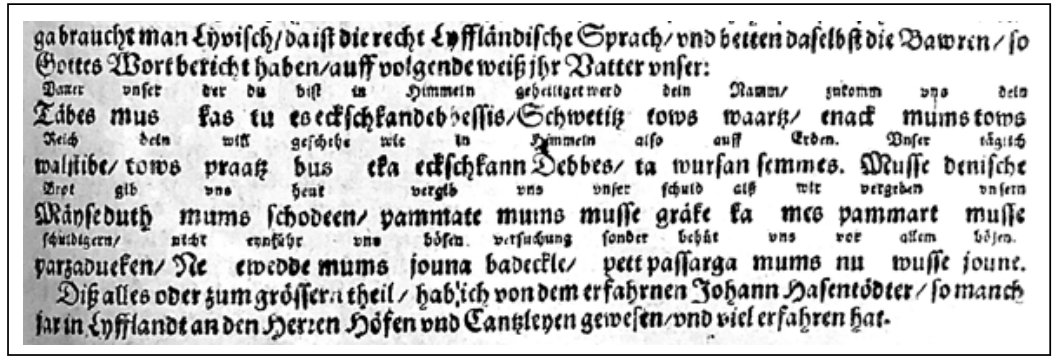

\section{1. attēls. Izvilkums no S. Minstera Cosmographia, Das ist: Beschreibung der gantzen Welt (1628) ${ }^{26}$}

Apkopojot tēvreizes publicējumus $\mathrm{MK}_{\mathrm{v}}$ izdevumos, jāuzsver to daudzums un nosacīta dažādība. Būtiskākas novirzes no sākuma teksta rodas ar 1564. g. izdevumu un turpina vairoties līdz pat 1578. g. Acīmredzami uzlabojumi, proti, tuvināšanās pirmajam publicējumam, atrodami 1588. g. izdevumā un atkārtoti vēl 1592. g., tomēr laikam franču izdevumu ietekmē kopš 1598. g. ienāk jaunas korekcijas, kas paturētas līdz pat pēdējam MK vācu izdevumam.

\subsection{Tēvreizes Minstera kosmogrāfijas izdevumos latīņu valodā (MK $\mathbf{M a t}_{\text {lat }}$}

Par nepieciešamību vācu valodā sacerētu darbu izdot latīniski ieminējies pats Minsters kādā vēstulē, kurā teicis, ka pēc vācu valodas pratēju atzinības vinamam nekas cits neesot atlicis, kā gatavot „starptautisko“ variantu (Mclean 2007: 186). Pirmā $\mathrm{MK}_{\text {lat }}$ paša Minstera tulkojumā ${ }^{27}$ nāca klajā jau 1550. g. un neilgi pēc tam izdota ar grozījumiem vēl piecas reizes: 1552. g. (divi izdevumi), 1554. g., 1559. g. un 1572. g. Mēdz teikt, ka toreizējai lingua franca izdotajai grāmatai bijusi liela un varbūt pat lielāka ietekme nekā vācu izdevumam (Davies 2011: 356). To daḹeji atbalsta arī latviešu tēvreizes

${ }_{25}$ Par atstarpi starp šiem vārdiem ir l̦oti grūti spriest (sk. 1. attēlu), jo arī vārds Debbes atstāts ar lielo sākumburtu.

${ }^{26}$ Hercoga Augusta Volfenbiteles bibliotēkas eks. (sign. A: 12.4 Hist. $2^{\circ}$ ).

27 Fēgelins (Vögelin 1882: 122) raksta, ka pirmo tulkojumu latīṇu valodā lielākoties veicis pats Minsters, bet to pilnveidojis Hugo fon Amerongens (Hugo von Amerongen). Arī jāteic, ka 1550. g. izdotie Minstera $\mathrm{MK}_{\mathrm{v}}$ un $\mathrm{MK}_{\text {lat }}$ nav identi izdevumi tikai citā valodā. 
fragmenta analīze - redzams, ka vēlākie izdevumi balstās latīṇu, nevis vācu variantā (sk. 4.1. shēmu).

Labi zināms, ka pirmā latviešu tēvreize 1550. g. iespiesta gan vācu, gan latīnu valodā izdotajā Minstera kosmogrāfijā, taču pareti tiek uzsvērts, ka tās ar vienu mēnesi datētajās grāmatās atškiras. Tiesa, atšksirīības nav būtiskas un, iespējams, radušās, tekstu pārrakstot no kāda kopēja avota. Lai gan tās aplūkojis Draviņš (1952: 221) ${ }^{28}$, skaidrības labad jāsniedz arī te: $\mathrm{MK}_{\mathrm{v}}$ eckfchan, bet $\mathrm{MK}_{\text {lat }}$ eckfchkan, Schwetitz - fchwetitz, enack - Enack, eckfchan - eckfchkan, Debbes/ - debbes, Måyfe - måyfe, důth - duth, müm $\beta$ - mums, můms mums, divreiz muße - muffe, meß - mefs, Ne wedde - Ne euuedde, badecklebadekle, wưffe - wuffe; vēl dažviet atšksiras interpunkcija (sal. 1. un 18. tēvreizi pielikumā). Tātad, lai gan ir paturēta daḷẹji vāciskā rakstība, piem., $w$ vai $\stackrel{e}{a}$, burtu $\ddot{u}, \stackrel{e}{u}$ un $u$ rakstība $\mathrm{MK}_{\text {lat }}$ nav saglabāta. Pamatojot tieši ar šo burtu rakstību, Draviņšs (1952: 222) hipotētiski min, ka ủ un ü rakstība vācu izdevumā ir drukas kḷūda, jo to vietā būtu gaidāms vāciešiem tajā laikā ierastais ů.

Kā var secināt no piemēriem, atšķirības ir lielākoties rakstībā, izņemot divas ne tik skaidras. Vispirms $\mathrm{MK}_{\text {lat }}$ abos vārda eckfchkan pierakstījumos atrodami divi $k$ burti, bet pirmajā vārdā vācu izdevumā - viens. Kā jau līdzīgi norādījis Draviņš (1952: 233), visticamāk, sākotnējā variantā bija divi $k$ burti, bet vācu izdevumā tā ir, iespējams, drukas vai rakstības kḷ̂uda. ${ }^{29}$ Otra neskaidrība ir Ne euuedde lietošana latīṇu variantā, kur $e$ izskatās kā verba priedēklis - wedde un ewedde 'ieved' (kā enack 'ienāk'). ${ }^{30}$ Viena izskaidrojuma nav, eksistē vien minējumi, kuri bez papildu pierādījumiem var būt tikpat patiesi, cik kḷūuaini. Pirmkārt, tā var būt nejaušība, ka $\mathrm{MK}_{\text {lat }}$ atkārtots iepriekšējais burts. Tiesa, šo iespēju noliedz Draviņš (1952), pēc kura domām, nejauši pielikts burts vārda sākumā ir maz ticams, it īpaši tāds, kuru pēc valodas log̣ikas arī varētu gaidīt tur esam. Tomēr te piebilstams, ka tas nebūt nav neiespējams, jo vēlākajos MK izdevumos $k a$ vietā rakstīts $e k a$ (t. i., ka ekfchkan $\rightarrow$ eka kfchkan). Otrs minējums - par to Draviņš (1952: 224) izteicies „,bez šaubām“ - Hāzentētera iesniegtajā variantā $e$ - jau bijis, taču vācu izdevumā kādu iemeslu dēḷ pazudis. Tā iemesls, pēc Draviņa

${ }^{28}$ Jāpiebilst, ka Draviņš (1952: 221) ir uzrādīịis vienu atškisirību vairāk (lat. esot måyfse), tomēr nevienā no pārskatītajiem latīṇu eksemplāriem šādi rakstītu vārdu maize autore nav redzējusi; arī paša Draviņa (1952: 216) sniegtajā latīṇu kopijā tā nav rakstīts.

29 Iespējama vēl cita hipotēze - jau sākotnējā Hāzentētera variantā pirmais lietojums bija ar vienu $k$ (eckfchan), tomēr latīṇu izdevumā, vienādojot ar otru eckfchkan, arī pirmajā iesprausts otrs $k$. Lai gan to noliegt nav viegli, noticēt arī, jo tieksme pēc vienādības rakstībā nedz $\mathrm{MK}_{\text {lat }}$, nedz pārējos MK izdevumos nav vērojama (sal. mums rakstību tai pašā tēvreizē).

${ }^{30}$ Jāpiebilst, ka variēšanās vērojama arī pirmajās tēvreizēs rokrakstā, sal. Grūnava (Grunau) tēvreizē newede munis lawnan Padoman, bet Bruno - Neekwedfe mums lounam badeklems. 
domām, var būt starp ne un wedde esošā aizdomīgi liela atstarpe, kura rādot, ka kāds burts no rindinas salikumā izkritis vai tml. Tomēr tam grūti noticēt, jo tikpat liela vai līdzīga atstarpe starp šiem vārdiem ir arī vēlākajos izdevumos, kuros latviešu teksts salikts piecās rindin̄ās un, lai aizpildìtu veselu rindiṇu, nedaudz pastiepts sānos. ${ }^{31}$ Tādēḷ, pieņemot Draviņa minējumu, ka sākotnēji bija ewedde, drīzāk būtu jādomā, ka tās atmešana ir $\mathrm{MK}_{\mathrm{v}}$ gatavošanas procesā radusies klịuda, pārrakstot vai liekot burtus.

Ne mazāk mīklains ir 1552. g. kosmogrāfijas izdevums latīņu valodā. Lai gan iepriekš minētie Minstera pētnieki nav norādījuši, laikam bijuši divi 1552. g. MK varianti. Pārbaudot pieejamos 1552. g. MK eksemplārus dažādās bibliotēkās, pamanīts, ka vienā no Bavārijas Valsts bibliotēkā esošajiem (sign. Res/2 Geo.u. 51 a) latviešu tēvreize atškiras. Papētot izrādīịās, ka tieši 761.-792. lpp. (latviešu tēvreize atrodama 789. lpp.) izmantotas pirmā izdevuma lapas vai to salikums, līdz ar to arī tēvreizes teksts nāk no 1550. g. izdevuma (sal. 18. un 20. pierakstu pielikumā), kaut grāmata izdota ar 1552. g. datumu. ${ }^{32}$ Taču pārējie apskatītie 1552. g. eksemplāri nav kontaminējums, un latviešu tēvreize tajos no pirmā izdevuma atšksiras (sal. 18. un 19. pierakstu pielikumā). Otrā $M_{\text {lat }}$ no pirmās atškiras ar latīniskoto rakstību, un tas attiecas arī uz latviešu lūgšanu, piem., vācu $w$ vietā visur $u$, bet $\stackrel{e}{a}-$ ligatūra $x$. Ir vēl dažas citas nianses, kā: debbeffis $\rightarrow$ debbefsis, mums $\rightarrow$ moms, mefs $\rightarrow$ mefis, badekle pett $\rightarrow$ badeklepett. Pēdējās trīs ir acīmredzamas korektūras kḷ̂udas, taču tieši tās raksturo MK latīṇu izdevumus, jo paturētas visos vēlākajos, izñemot pēdējo.

Pilnīgi visi vēlākajos latīṇu MK izdevumos atrodamie publicējumi vairāk vai mazāk atškiras, tāpēc, lai gan parasti rakstībā atkārtotas vecās īpatnības, vērojamas arī jaunas. Piem., 1554. g. publicējums no 1552. g. atšksiras ar: Taebes $\rightarrow$ Tębes, męyfe $\rightarrow$ maeyfe, badeklepett $\rightarrow$ badecklepett (sal. 19. un 21. tēvreizi pielikumā). Daḷu no tām paturēiis arī ceturtais (1559. g.) $\mathrm{MK}_{\text {lat }}$, taču tajā ieviesušās vēl citas nianses: Tębes $\rightarrow$ Taebes, mus kas $\rightarrow$ muskas, Enack $\rightarrow$ enack, femmes $\rightarrow$ fẽmes, Muffe $\rightarrow$ mufle, graeke $\rightarrow$ gręke, parradueken $\rightarrow$ parraduekẽ, Ne $\rightarrow$ ne, paffarga $\rightarrow$ paflarga, uuuffe $\rightarrow$ uuffe, loune $\rightarrow$ loune. (interpunkcija) (sal. 21. un 22. tēvreizi pielikumā).

Iespējams, pēdējais (1572. g.) latīņu izdevums seko iepriekšējam (piem., aiz loune pirms Amen atrodama interpunkcijas zīme), tomēr sniedz labotu tēvreizi, jo pārējās iepriekš minētās ceturtā izdevuma rakstības pazīmes nav

31 Pirmajos pētìtajos vācu MK izdevumos latviešu tēvreize aizņem piecas rindinas, taču, sākot ar 1564. g. izdevumu, tā salikta četrās.

32 Arī citās minētā izdevuma vietās izmantotas lapas no pirmā latīṇu izdevuma, taču titullapa, sākums un beigas ir jaunajā, 1552. g. salikumā. 
novērojamas (sal. 22. un 23. tēvreizi pielikumā). Nav skaidrs, kurā avotā balstoties labots. N̦emot vērā jaunās pēdējā $\mathrm{MK}_{\text {lat }}$ pazīmes, t. i.: moms $\rightarrow$ mūs, eckfchkan debbes $\rightarrow$ ekfehkan debbes un badeklepett $\rightarrow$ badekle pett, var nedroši minēt, ka tas varējis būt pirmais (1550. g.) vai 1552. g. otrais izdevums (sal. 18., 20. un 22. tēvreizi pielikumā).

Secinot jāteic, ka, līdzīgi vācu izdevumiem, MK latīṇu valodā vērojama daudzveidība latviešu tēvreizes rakstībā, ko it īpaši raksturo šādas pazīmes: ne wedde vietā ne ewedde (visās $\mathrm{MK}_{\mathrm{lat}}$ ), mums vietā moms (1552.-1559. g.), meß vietā mefis (kopš 1552. g).

\subsection{Tēvreizes Minstera kosmogrāfijas izdevumos franču valodā $\left(\mathrm{MK}_{\mathrm{fr}}\right)$}

Laikā no 1552. g. līdz 1575. g. iznāca seši $\mathrm{MK}_{\text {fr }}$ izdevumi, un piecos no tiem latviešu tēvreizes pieraksts savstarpēji atšksiras. Pietiekami droši var apgalvot, ka tajos esošās latviešu tēvreizes pamatā nav bijis 1550. g. vācu publicējums, jo, līdzīgi kā latīņu izdevumos, eckfchan vietā $\mathrm{MK}_{\mathrm{fr}}$ ir eckfchkan, $N e$ wedde vietā $N e$ ewedde utt. Tomēr tas arī nav identisks $M_{\text {lat }}$ esošajam, piem., praats - praatz, badekle - badeckle, bet måyfe - måife, tāpat atmests lūgšanas apstiprinājums Amen (sal. arī 18. un 24. tēvreizi pielikumā).

Jāteic, ka $\mathrm{MK}_{\mathrm{fr}}$ tēvreizes starp visiem kosmogrāfijas izdevumiem atšksiras visvairāk. Tās droši veido atsevišksu kopu (sk. 4.1. shēmu), ko var noteikt pēc lūgšanas ievadvārdiem - Mus tabes -, jo visos pārējos Minstera izdevumos ir Tåbes mus dažādās variācijās rakstībā. Nav acīmredzama izskaidrojuma, kā radusies šì vārdu secības maiņa. Taču par šādu variāciju lūgšanas uzrunā nav jābrīnās, jo tā bija sastopama arī 16. gs. vācu tradīcijā (Unser Vater), kā arī vēāāajās latviešu grāmatās (Vanags 1996: 85-86). Lai gan grūti izskaidrot, nav pamata teikt, ka tai bijis kāds cits avots, - tiek uzskatīts, ka tulkojumu franču valodā veicis Minsters pats (Hantzsch 1898: 142). Turklāt maz ticams, ka kāds no gatavošanas procesā iesaistītajiem cilvēkiem būtu pārzināijis latviešu valodu; arī interlineārais tulkojums franču valodā nav precīzs, piem., virs vārda tows tulkots soit 'ir', nevis ton 'tavs', utt. Iespējams, vārdu secības maiņa te jāsaista ar tēvreizi franču valodā, kas tai pašā $M K_{\text {fr }}$ latviešu tēvreizes starprindu tulkojumā ir nośtre Pere ${ }^{33}$, tātad tieši mūsu tềs, nevis otrādi: ${ }^{34}$

33 Arī pašreizējā 2017. g. aprobētajā tulkojumā ir: „Notre Père, qui es aux cieux, que ton nom soit sanctifié, que ton règne vienne, que ta volonté soit faite sur la terre comme au ciel $\langle\ldots\rangle$." (sk. de Kerimel 2017)

34 1565. g. vai 1568. g. $\mathrm{MK}_{\mathrm{fr}}$ tēvreizes fotokopija (defektīva, bez beigām) atrodama avīzē Laiks, kas izdota 1974. g. 12. janvārī, 5. lpp. Tās digitālā kopija atrodama www.periodika.lv. 
gostre Pere qui tues es cieax fantifie foit tonnom, adrienne ìnous tols Mus tabes kas tues' eckfchkan debbeflis, fehretitz tows maartz, Enack mums tors royaume, ta uolusté foitfaite comme auciel, ainfi furli terre," noftre quotidien pain walftibe, toms praatz bus ka ekfchkan debbes ta wurfan femmes, Muffe denifche msife donne nous atuiourdhuy, pardomne nous noz debtes commenouspardonnons innoz debturs duch mums fchodeen, pammate mums muffe grâke kamefs pammat muffe parraducken

\section{Vniuerfelle liure III.}

\section{9}

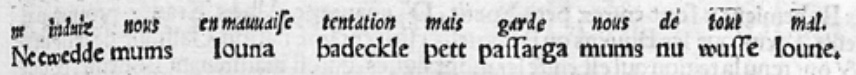

\section{Iay en cecy pour la plus grand part, dufufdit Iehan Tuelieure, homme.} fort experimenté en beaucoup de chofes.

\section{2. attēls. Izvilkums no S. Minstera La Cosmographie vniverselle (1552) ${ }^{35}$}

Tomēr nekur citur vārdu secība latviešu tekstā nav mainīta, lai gan tam būtu bijis iemesls, ja, gatavojot tulkojumu, būtu izlemts ievērot franču teksta vārdu secību (sal. 16. gs. pastāvējušo tēvreizi ${ }^{36}$ vai, piem., ar M. Belska publicējumu ${ }^{37}$ ). Tātad, lai cik interesants būtu šādas vārdu kārtas maiņas iemesls, atbilde vēl jāmeklē. Varbūt skaidrāks tas kḷūtu, uzejot kādus avotus par Minstera franču izdevuma gatavošanas vēsturi.

Raugoties pašos $\mathrm{MK}_{\mathrm{fr}}$ tēvreizes publicējumos, jāteic - kaut īpašais sākums sakrīt visos, tikai divi (1565. g. un 1568. g.) izdevumu pieraksti ir identiski. Atškirīibas starp izdevumiem ir lielākoties korektūras ziņā, piem., otrais $\mathrm{MK}_{\mathrm{fr}}$ no pirmā atšķiras ar eckfchkan $\rightarrow$ eckfckan, debbeffis $\rightarrow$ debbefsis, pammate mums $\rightarrow$ pammatemums utt. (sal. 24. un 25. tēvreizi pielikumā). Grūti spriest, vai atškirīību ieviešana bijusi apzināta, tomēr vērojamas arī izmaiņas, kas acīmredzami radītas ar nodomu. Par tādām ir jāsauc pāreja no vāciskās rakstības, kas laikam ienākusi ar minētā 1550. g. latīṇu izdevuma starpniecību, uz antīkvā rakstīitiem tekstiem raksturīgāku, piem., vācu $w$ 1556. g. $\mathrm{MK}_{\mathrm{fr}}$ mainīts uz uu (wuffe $\rightarrow$ uuuffe), izņemot atsevišksus gadījumus,

35 Bāzeles Universitātes eksemplārs (sign. UBH EU I 84), digitālā kopija atrodama www.e-rara.ch kolekcijā.

36 Piem., 1555. g. Gesnera Mithridates krājumā (26. lpp.): „Nostre pere qui es és cieulx, ton nom foit fanctifié. ton royaume aduiene. ta uolunté foit faicte ainfi en la terre comme au ciel."

37 Belska publicētās tēvreizes pamatā ir poḷu tēvreize, kam mazākos burtos sniegts neprecīzs tulkojums latviešu valodā. Teksta transkripcija atrodama Meringera (1895: 489) vai Zēvera (1929: 514) darbā. 
kā walftibe $\rightarrow$ vualftibe, tows $\rightarrow$ tous, wurfan $\rightarrow$ vurfan; tāpat $\mathrm{MK}_{\mathrm{fr}} \stackrel{e}{a}$ vietā rakstīti parastie $a^{38}-$ måife, gråke $\rightarrow$ maife, grake. Šìs otrā $M K_{\text {fr }}$ izdevuma īpatnības paturētas trešajā (1560. g.) laidienā, taču arī tajā vērojamas sīkas atškirīības: touus uuaartz $\rightarrow$ tous uuaartz, pammatemums $\rightarrow$ pammate mums, pammat $\rightarrow$ pãmatt (sal. 25. un 26. tēvreizi pielikumā). Savukārt kāda škịietami sīka kḷūda 1560. g. izdevumā izrādīịās krietni lielāka - louna un loune vietā lietots Iouna un Ioune, proti, sākotnējā mazā $l$ burta vietā nepareizi ielikts lielais $I$. Rezultātā notikusi netǐša leksiskā maiņa - sestajā lūgšanā lūdzot neievest mūs jaunā nevis ḷaunā badecklē -, kas vēl ilgus gadus ceḷoja no viena avota citā. Aizdomas par nejaušību atbalsta arī tas, ka vēlākajā 1565. g. un identajā 1568. g. izdevumā šãdi salikts laikam tikai pirmais segments (Ne euuedde mums Iouna badeckle pett paffarga mums nu uuuffe louue) $)^{39}$, tomēr 1575. g. jau abi (Ne euuedde mums Iouиa badeckle : pett paffarga mums nu uuuffe Iоииe).

Kopš ceturtā (1565. g.) MK fr izdevuma latviešu tēvreizes pierakstā ienāk vēl divas būtiskas korekcijas, kas nepārtraukti atkārtojas arī 17. gs. tēvreižu krājumos, t. i., ka ekfchkan vietā eka kfchkan un pammat vietā pammart, kas nepārprotamas un latviešu valodas lietotājam viegli identificējamas kā korektūras kḷūdas. Kā minēts, 1565. g. un 1568. g. $\mathrm{MK}_{\mathrm{fr}}$ izdevumi ir identi (sal. 27. un 28. tēvreizi pielikumā). No iepriekšējā (1560. g.) izdevuma tie atšķiras ar šīm īpatnībām rakstībā: uuaartz, vietā uuaartz: (interpunkcija), touus praats $\rightarrow$ tous praatz, vualftibe $\rightarrow$ uualftibe, vurfan $\rightarrow$ uurfan, fchodeen $\rightarrow$ fchodéen, parradueken $\rightarrow$ parraducken, Iouna $\rightarrow$ Iouua, Ioune $\rightarrow$ louue.

Pēdējais (1575. g.) franču MK izdevums laists klajā neilgi pēc piektā publicēšanas, taču stipri atškiras ne vien apjoma dēḷ (izdots divos sējumos). To no jauna tulkoja un ievērojami papildināja zināmais franču rakstnieks Fransuā de Belforē (François de Belleforest) (Ruland 1962: 91). Lai gan sestais $M_{\text {fr }}$ būtiski atškşiras no iepriekšējiem izdevumiem, izmainas latviešu tēvreizē, kas atrodama pirmajā sējumā (1624. lpp. $)^{40}$, ir minimālas, t. i.: debbefsis $\rightarrow$ debbeffis, uuaartz $\rightarrow$ uuaarts, fchodéen $\rightarrow$ fchodeen, pārējās izmainas ir interpunkcijā (sal. 28. un 29. tēvreizi pielikumā). Tas nozīmē, ka, gatavojot šo izdevumu, tēvreizes teksts netika salīdzināts ar agrākiem vai citvalodu avotiem, jo visas iepriekš minētās franču izdevumu korekcijas ir atkārtotas.

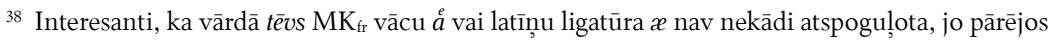
avotos autori centušies pēc iespējām šo burtu paturēt, tā vietā rakstot vēl $\ell$ (itâla izdevumos) vai vēlāk arī $\ddot{a}$.

39 Jāteic, pat apzinoties $I$ un $l$ atškirīibu, šos burtus drukātā tekstā ir l̦oti grūti atšksirt.

40 Pārskatītajos šì izdevuma eksemplāros (sk. avotu sarakstā) ir kḷūda paginācijā, jo 1620. lpp. seko 1623. lpp.
} 


\subsection{Tēvreizes Minstera kosmogrāfijas izdevumos itāḷu valodā $\left(\mathrm{MK}_{\mathrm{it}}\right)$}

Vēlākais pētāmais kosmogrāfijas tulkojums veikts itāḷu valodā. Pirmo reizi tas izdots 1558. g. Bāzelē, vēlāk atkārtoti izdots Venēcijā un Ķelnē. Droši zināma iespējami trešā, 1575. g. Koelnē izdotā grāmata, kas saglabājusies dažādās bibliotēkās, tomēr ziņas par Venēcijas izdevumu literatūrā ir trūcīgas. Šis izdevums nav datēts, līdz ar to pastāv dažādi uzskati - Hančs (Hantzsch 1898: 156) domā, ka tas bijis 1575. g., tomēr Burmeisters (1969: 183) piedāvā 1571. g. (ar jautājuma zīmi), bet Rulands (1962: 91), ņemdams vērā iespiešanai izmantoto Bāzeles salikumu, spriež, ka Venēcijas izdevums laists klajāa agrāk, posmā starp 1558. g. un 1571. g.

Itālu izdevumi no pārējām pētāmajām MK atšksiras. Pirmkārt, to izdevumu ir vismazāk, otrkārt, visos paturēta tāda pati paginācija un liekas, ka tās ir viena salikuma grāmatas, lai gan ar atškirirīgām titullapām un vietām izdzēstu tekstu. $\mathrm{MK}_{\text {it }}$ izdevumu skaitu un dažu vietu dzēšanu laikam ietekmējis tas, ka Minsters bija iekḷuvis Romas katoḷu baznīcas aizliegto autoru reg̣istrā. ${ }^{41}$

Ëfthiaca, ma ceica Riga la Liuonica.I côtadini diucnuti Chriftiani uicini à quefta citta di cono il paternoftro in quefta forma.

Padre nofrocbe fai ne cieli fisfaniificato il tro nome nenga i noi il two Tçbes mus kas tu es eckfchkã debbefsis, fchuuetitz touus uuaartz, Enackmoms touus Regno fis fattslauolontstus come is ciclo cofi in terrs,il noffro cottidisno pane uualftibe, touus praatsbus ka ekfchka debbestauuurfan femmes, Muffedenifchem cyfe, ds inoi hoggi, rinetti à noi itofiri debiti,comenoi glivimettianodinofiri debitori duth mums fehodeč, pämate mums muffe graekeka mefis pammat mufie parraducken. onos ciindarre in tentatione, ma libersti da oghi male amen. Ne cuuedde mums louna badecklepettpaffarga mum̄s nuuuuffeloune Âmen.

Quefte cofe in buona partel'ho da Giouannileporicida huomo dimolte cofe edimoltipaefi prattichifsimo.

\section{3. attēls. Izvilkums no S. Minstera Sei Libri Della Cosmografia Vniuersale} $(1558)^{42}$

Latviešu tēvreize visos $\mathrm{MK}_{\mathrm{it}}$ izdevumos iespiesta ne vien identā lappusē, bet arī salikumā (sal. 30., 31. un 32. tēvreizi pielikumā), un tas tikai

${ }^{41}$ Bijuši vairāki Romas katoḷu baznīcas reǵistri, bet 1559. g. Index Librorum Prohibitorum izdevumā Minsters atrodams pat divreiz - gan pie $m$ (Munfterus), gan pie $s$ (Sebaftianus Munfterus) burta (sk. Petrella 2006).

42 Portugāles Nacionālās bibliotēkas eks. (sign. CCBE s. XVI M 2247), digitālā kopija atrodama Portugāles Nacionālās bibliotēkas digitālajā krāiumā. 
apstiprina kartogrāfa Rulanda (1962: 91) secinājumus, kas izdarīti, pētot MK kartes, ka abi vēlākie ir pirmās (1558. g.) MK it atkārtoti izdevumi (sal. arī Mclean 2007: 175). Pietiekami droši var apgalvot, ka itāḷu MK atrodamo latviešu tēvreižu pamatā bija toreiz jaunākais (1554. g.) latīņu tulkojums. To apliecina izšķ่irošā vārda tềs rakstība tębes, kas nav atrodama nevienā citā MK izdevumā (sal. 20. un 30. tēvreizi pielikumā). Atkārtotas arī vienīgi latīṇu izdevumiem raksturīgās kḷūdas, piem., mums vietā moms, mefs vietā mefis vai kopā sarakstìti divi vārdi - badecklepett. Lai gan $\mathrm{MK}_{\mathrm{it}}$ tēvreize nav identa latīniskajā avotā esošajai, to atškirirības ir ḷoti sīkas, varējušas rasties, liekot tekstu: četras reizes burtus $n$ un $m$ nomainījušas diakritiskās zīmes (eckfchkã (divas reizes), fchodeẽ, pãmate), arī mums vietā atrodams $m u \bar{m} s^{43}$ un vienreiz divi atsevišksi vārdi sarakstīti kopā - praatsbus.

\section{Hāzentētera tēvreizes atkalizmantošana}

4.1. Apkopojot atsevišķi teikto, MK iespiestās latviešu tēvreizes sakarus iespējams attēlot arī shēmā. ${ }^{44}$ Tajā teksta atkalizmantošanas virzieni ir noteikti pēc kopīgajām iepriekš aplūkotajām korekcijām, kas lielākoties ir rakstībā. Jāuzsver, ka secinājumi izdarīti, balstoties tikai uz vienu fragmentu - latviešu tēvreizes publicējumu -, un nav attiecināmi uz visu izdevumu, proti, tas nenozīmē, ka 1598. g. $\mathrm{MK}_{\mathrm{v}}$ izdevums no jauna tulkots, par pamatu ņemot 1575. g. $\mathrm{MK}_{\mathrm{fr}}$.

Shēmā var redzēt, ka, neskaitot identos pierakstus, pastāvējuši vismaz 23 latviešu tēvreizes varianti vien kosmogrāfijas izdevumos. Tā arī rāda, ka izdalāmi trīs galvenie tēvreizes pieraksta paveidi jeb MK tradīcijas. Jau kopš paša sākuma - 1550. g. - var izškisirt divus paveidus: vācu un latīṇu, bet, sākot ar 1552. g., vērojams arī trešais spilgtais paveids - franču MK izdevumi. Interesantā kārtā izdalīto tradīciju pirmos publicējumus sagatavojis tas pats cilvēks - S. Minsters. Tādẹ̄̂, pieņemot, ka Minsters latviešu valodu nav pratis (tēvreizes pierakstu saņēmis no Hāzentētera), laikam būtu domājams, ka visi paveidi radušies nevis apzinātu lingvistisku izmaiņu, bet dažādu ekstralingvistisku faktoru (tipogrāfijas iespēju, nevērīguma, laikmeta tradīciju u. c.) ietekmē.

${ }^{43}$ Virs $m$ burta nav tildes kā iepriekšējos piemēros, bet kāda svītriṇa.

${ }^{44}$ Savā ziņā shēmu var apvienot ar Draviņa (1965: 26) sniegto, kurā atspoguḷotas arī agrākas tēvreizes rokrakstā. 


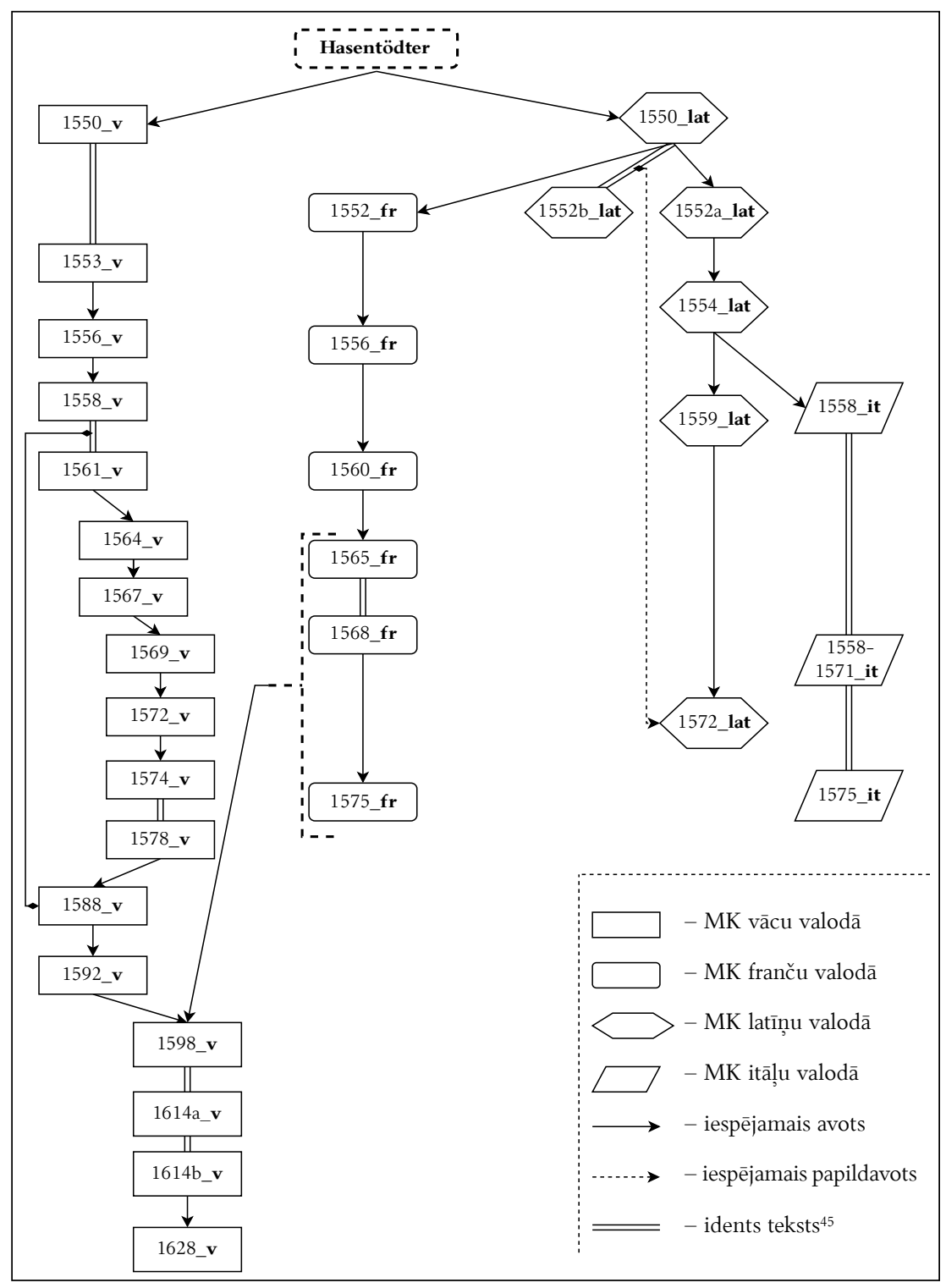

Shèma. Iespiestās latviešu tēvreizes hipotētiskie atkalizmantošanas virzieni

45 Vārds idents attiecināms uz latviešu tekstu, bet ne teksta salikumu, t. i., vārdu pārnešana jaunā rindā var atšksirties. 
4.2. Pārrunājot iespējamos teksta atkalizmantošanas ceḷus, vēl jāmin shēmā neatspoguḷotas tēvreižu pierakstu atškirīibas pakāpes, kad teksts nav idents. Iepriekš rakstā katras grāmatas pieraksta sakritība ar agrākajiem izdevumiem raksturota, sniedzot konkrētus piemērus, taču ir iespējams uz to paskatīties vispārīgāk, izmantojot digitālo rīku Lexos. Skatoties formāli burts burtā uz tēvreizes pierakstiem, to atškirīibas no diviem pirmajiem 1550. g. publicējumiem attēlo šì diagramma: ${ }^{: 6}$

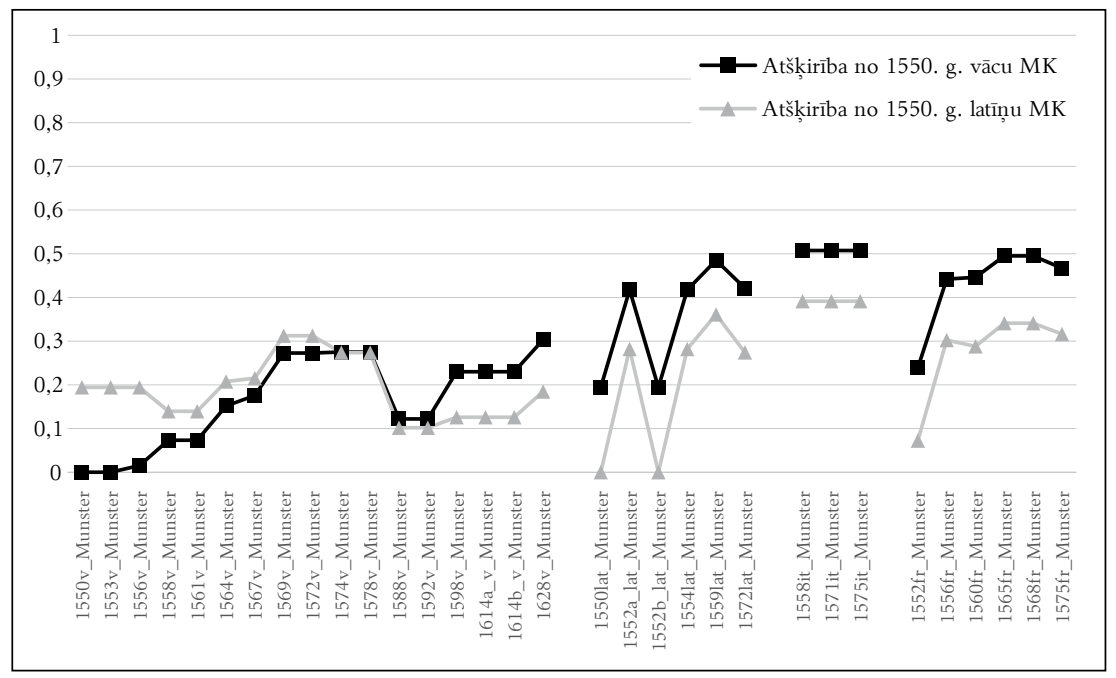

\section{Diagramma. Latviešu tēvreizes publicējumu MK izdevumos sakritība burts burtāa ${ }^{47}$}

Protams, attēlotais rezultāts ir ḷoti nosacīts. To vērtējot, jāpatur prātā arī attiecīgo izdevumu rakstības atšksirības, kas ietekmē rādītāju, piem., vācu $w$ bieži citos avotos atbilst $v v, u u$ vai $v u$, bet $\stackrel{e}{a}-x, a e, e$ vai $a$ utt. Tomēr dažas tendences tik un tā ir vērojamas. Viena no vispārīgākajām - neatkarīgi no salīdzināmā teksta, atšksirības no pirmajiem izdevumiem laika gaitā vairojas, un tas nozīmē, ka latviešu tēvreize MK izdevumos nebūt nav bijusi nemainīga. Arī - ar pirmajā $\mathrm{MK}_{\mathrm{v}}$ esošo pierakstu sakrīt mazāk izdevumu nekā ar $\mathrm{MK}_{\text {lat }}$, taču to, iespējams, ietekmē attiecīgās grāmatas rakstības paņēmiens.

46 Salīdzinājums ar diviem pirmajiem publicējumiem ir sniegts tādēḷ, ka nav vienprātības, kurš tomēr bija pirmais vai tuvāks īstajam Hāzentētera variantam.

47 Diagrammā atspoguḷota teksta kosinusa līdzība ( 0 = pilnīgi sakrīt, bet 1 = nesakrīt $)$, neieklaujot atškirīibas interpunkcijā un lielo burtu lietojumā. 
Skatot pierakstu sakritību tikai ar vācu 1550. g. izdevumu, redzama interesanta tendence, ka pirmie MK izdevumi attiecīgā valodā, kurus gatavojis pats Minsters, bieži ar $\mathrm{MK}_{\mathrm{v}}$ sakrīt vairāk (rezultāts tuvāk 0) nekā vēlākie, ko gatavojuši jau citi cilvēki. Izñēmums ir tikai MK itālu valodā publicētie izdevumi, kas ir identiski, to lielo atškirīibu noteic tas, ka tulkojums balstās uz vēlāko (1554. g.) MK lat. Citiem vārdiem — jo vēlāk izdots publicējums, jo vairāk tas atškiras no 1550. g. $\mathrm{MK}_{\mathrm{v}}$ izdevuma. Tas it īpaši spilgti redzams vācu izdevumos - kopš pēdējās 16. gs. $\mathrm{MK}_{\mathrm{v}}$ vairāk sakrīt pat ar pirmo $\mathrm{MK}_{\mathrm{lat}}$ nekā ar pierakstu pirmajā vācu izdevumā un pats pēdējais (1628. g.) publicējums visvairāk atškiras no pirmā $M K_{v}$. Vērtējot publicējumu sakritību ar 1550. g. $\mathrm{MK}_{\text {lat }}$, jāteic, ka tendence ir līdzīga un rāda - lai gan iznākuši neilgi pēc pirmizdevuma, rakstība turpmākajos izdevumos no pirmā atšşiras pietiekami daudz.

\section{Secinājumi}

1. Rakstā pētīti 32 latviešu tēvreizes publicējumi, kas atrodami S. Minstera vācu, latīṇu, franču un itālu valodā izdotajā kosmogrāfijā (1550-1628). Tos izanalizējot, nonākts pie diviem pēc pirmā acu uzmetiena pretrunīgiem apgalvojumiem: visās MK atrodama tā pati tēvreize, taču visbiežāk tā atškiras. T. i., tikai viens no vēlākajiem publicējumiem — otrais pētītais MK vācu izdevums (1553) -, lai gan ir jaunā salikumā, burts burtā seko 1550. g. pierakstam. Pārējos avotos latviešu tēvreizes pieraksti savā starpā vairāk vai mazāk atškiras, un tikai retos gadījumos to pieraksts attiecīgās valodas izdevumos ir idents.

Tādējādi secināts, ka 32 MK laidienos atrodami vismaz 23 Hāzentētera tēvreizes paveidi. Taču jāuzsver, ka atšksirības starp paveidiem nav būtiskas, vērojamas galvenokārt rakstībā. Te izņēmums būtu kosmogrāfijas izdevumi franču valodā, kuru sniegtās latviešu tēvreizes uzrunā ir arī vārdu secības maiņa. Tomēr škiet, ka vairākums izmaiņu diez vai bijušas apzinātas, drīzāk radušās nejauši, pārrakstot vai liekot tekstu. Nejaušỉbu apliecina arī tādi gadījumi kā MK tēvreizes 7. lūgšanā esošs lūgums pasargāt no visa jauna, nevis ḷauna ( $l$ burts interpretēts kā lielais $i$, kas vēlākajos izdevumos pārvērties par mazo $j$ ). Lai gan vērojamas arī tādas izmaiņas, ko varētu saukt par labojumiem, piem., prauts $\rightarrow$ praats, to pamats bijis iepriekšējie MK izdevumi, nevis kādi citi vai latviešu avoti.

2. MK izdevumos atrodamās latviešu tēvreizes pieraksta kḷūdu tipolog̣ija lạuj tos klasificèt trīs galvenajās MK tradīcijās: 1) vācu, 2) latīṇu, kam seko arī itāla izdevumi, un 3) franču. Tās radušās nevis apzinātu lingvistisku izmaiņu, bet dažādu ekstralingvistisku faktoru ietekmē. Tā secināts, zinot, ka šo variantu pirmos izdevumus gatavojis pats S. Minsters, kas latviešu valodu nav pratis (tēvreizes pierakstu saņēmis no Hāzentētera). 
Visām tradīcijām raksturīgi kādi zīmīgi sìkumi tēvreizes tekstā, kas vērojami vien̄igi izdevumos attiecīgajā valodā. Tāpēc pašlaik zināmajās MK tēvreizēs iespējams izšķirt š̄s izmainas, kuras, uzejot kādu jaunu publicējumu, var palīdzēt identificēt avotu vai avotvalodu:

- $\quad$ ne wedde vietā ne ewedde - sākot ar latīṇu 1550. g. MK;

- $\quad$ mums $\rightarrow$ moms, mefs $\rightarrow$ mefis - sākot ar latīnu 1552. g. MK;

- $\quad$ Tábes mus $\rightarrow$ mus tabes - sākot ar 1552. g. franču MK;

- louna $\rightarrow$ Iouna - sākot ar 1560. g. franču MK;

- paffarga $\rightarrow$ pafferga - 1564.-1578. g. vācu MK;

- pammat $\rightarrow$ pammart, ka ekfchkan $\rightarrow$ eka kfchkan - sākot ar 1565. g. franču MK;

- $\quad$ praats $\rightarrow$ prauts, parraduekẽ $\rightarrow$ parreduekẽ - 1567.-1578. g. vācu MK.

Tātad ne tikai pati Minstera kosmogrāfija nav bijusi nemainīgs izdevums, bet nosacìti liela dažādība vērojama arī tās izdevumos atrodamās latviešu tēvreizes pierakstā. Līdz ar to, runājot par Hāzentētera tēvreizi kā avotu, būtu ņemams vērā, ka kosmogrāfijas izdevumos pastāvēja vismaz trīs lielie varianti ar daudziem paveidiem.

\section{Saīsinājumi}

$\mathrm{MK}=\mathrm{S}$. Minstera kosmogrāfija (visi izdevumi kā kopums)

$\mathrm{MK}_{\mathrm{it}}=\mathrm{S}$. Minstera kosmogrāfija itāḷ valodā.

$\mathrm{MK}_{\mathrm{fr}}=\mathrm{S}$. Minstera kosmogrāfija franču valodā.

$\mathrm{MK}_{\text {lat }}=\mathrm{S}$. Minstera kosmogrāfija latīņu valodā.

$\mathrm{MK}_{\mathrm{v}}=\mathrm{S}$. Minstera kosmogrāfija vācu valodā.

\section{Avoti}

Münster, Cosmographei || oder beschreibung aller lån/||der/ herschafften/ fürnemsten || Sebastian stetten/geschichten/gebreūchē/ hantierungen etc. ietz || zum drittem mal trefflich 1550. sere durch Sebastianum || Munsterũ <...>. Basel: Petri. VD16 M 6693. Freiburgas Alberta-Ludviga Universitātes bibliotēkas eks. [sign. Br.: J 4763,d], Bavārijas Valsts bibliotēkas eks. [sign. Res/2 Geo.u. 48]. Digitālā versija: Münchener Digitalisierungszentrum; dccccxxxij. lpp.

Münster, COSMO||GRAPHIAE || uniuersalis Lib.VI. in || quibus, iuxta certioris fidei Sebastian scriptorum || traditionem describuntur, || Omniũ habitabilis orbis partiũ situs ... || 1550. Regionum Topographicae effigies. || ... Omnium gentiũ mores, leges, religio ... || Item regum \& principum genealogiae. || Autore Sebast.Munstero. || <...>. Basileae: Heinrich Petri. VD16 M 6714. Bavārijas Valsts bibliotēkas eks. [sign. Hbks/E 4], Nacionālā Osoliņska institūta eks. [sign. XVI-4553], Džona Kartera Brauna bibliotēkas Providensā eks. [sign. J550 .M948c], Lionas publiskās bibliotēkas eks. [sign. Rés 105149], Romas Casanatense bibliotēkas eks. [sign. BB IV 24]. Digitālā versija: Münchener Digitalisierungszentrum; 789. 1pp. 
Münster, COSMO||GRAPHIAE || uniuersalis Lib.VI. in || quibus, iuxta certioris fidei Sebastian scriptorum || traditionem describuntur,|| Omniũ habitabilis orbis partiũ situs ... || 1552a. Omnium gentium mores, leges, religio, res gestae, mu||tationes ... || Autore Sebast. Munstero. Basileae. VD16 M 6715. Bavārijas Valsts bibliotēkas eks. [sign. Res/2 Geo.u. 51], Nacionālā Osoliņska institūta divi eks. [sign. XVI.F.4512, XVI.F.4280], Romas Nacionālā centrālā bibliotēka [sign. 6. 16.N.8]. Digitālā versija: Münchener Digitalisierungszentrum; 789. lpp.

Münster, COSMO||GRAPHIAE || uniuersalis Lib.VI. in || quibus, iuxta certioris fidei Sebastian scriptorum || traditionem describuntur,|| Omniũ habitabilis orbis partiũ situs ... || 1552b. Omnium gentium mores, leges, religio, res gestae, mu||tationes ... || Autore Sebast. Munstero. Basileae. VD16 M 6716. Bavārijas Valsts bibliotēkas eks. [sign. Res/2 Geo.u. 51 a]. Digitālā versija: Münchener Digitalisierungszentrum; 789. lpp.

Münster, LA COS||MOGRA||PHIE VNIVER ||SELLE, CONTENANT || la situation de Sebastian toutes les parties du monde, | | auec leurs proprietez \& appartenances. || ... PAR SEBAST. 1552. MVNSTERE. [Basel]: [Heinrich Petri]. VD16 M 6707. Bāzeles Universitātes bibliotēkas eks. [sign. UBH EU I 84]. Digitālā versija: e-rara.ch; 888.-889. lpp.

Münster, Cosmographei || oder beschreibung aller lån-||der/ herrschafften/ fürnemsten || Sebastian stetten/geschichtẽ/gebreüchen ... || zům offterẽ mal trefflich seer durch || Sebastianũ 1553. Munsterũ gebessert ... <...>. Basel: Petri. VD16 M 6694. Bavārijas Valsts bibliotēkas eks. [sign. Hbks/E 5 f], Diseldorfas Universitātes un Valsts bibliotēkas eks. [sign. AG 15(2) ]. Digitālā versija: Münchener Digitalisierungszentrum; dccccxxxij. lpp.

Münster, COSMO||GRAPHIAE || uniuersalis Lib.VI. in || quibus iuxta certioris fidei Sebastian scriptorum || traditionem describuntur, || Omnium habitabilis orbis partium situs, 1554. pro/|| priaeque dotes. || ... Item omnium gentium mores, leges, religio ... || atque memorabilium in hunc usque an/| | num 1554.gestarum rerum Historia. | | Autore Sebast. Munstero. [Basileae]. VD16 M 6717. Bavārijas Valsts bibliotēkas eks. [sign. Res/2 Geo.u. 53], Romas Nacionālā centrālā bibliotēka [sign. 6. 18.N.1]. Digitālā versija: Münchener Digitalisierungszentrum; 789. lpp.

Münster, Cosmographei || oder beschreibung aller lån/||der/ herrschafften/ fürnemsten || stetten/ Sebastian geschichtẽ/ gebreüchen ... || zům offterẽ mal trefflich seer durch || Sebastianũ Munsterũ 1556. gebessert ... <...>. Basel: Petri. VD16 M 6695. Bavārijas Valsts bibliotēkas eks. [sign. Res/2 Geo.u. 54]. Digitālā versija: Münchener Digitalisierungszentrum; dccccxxxij. lpp.

Münster, LA COS||MOGRA||PHIE VNIVER||SELLE, CONTENANT || la situation de Sebastian toutes les parties du monde, || auec leurs proprietez \& appartenances. || ... continuant 1556. ius=| |ques à l'an 1555. || PAR SEBAST. MVNSTERE. [Basel]: [Heinrich Petri]. VD16 M 6708. Vilınas Universitātes bibliotēka [sign. M 501]. Digitālā versija: Viḷnas Universitātes bibliotēkas digitālajā krājumā; 888.-889. lpp.

Münster, SEI LIBRI || DELLA || COSMOGRAFIA VNI||uersale, ne quali secondo che Sebastian n'hanno || parlato i piu ueraci scrittori son disegnati, || I siti de tutte le parti del mondo 1558. habitabile \& le proprie doti:|| Le Tauole topographice delle Regioni.|| Le naturali qualita del terreno, onde nascono tante diferenze, \& uarieta || dicose, \& animate \& non animate.|| ... AVTORE SEBASTIANO MVNSTERO. [Basileia]: Henrigo Pietro. VD16 M 6712. Portugāles Nacionālās bibliotēkas eks. [sign. CCBE s. XVI M 2247]. Digitālā versija: Portugāles Nacionālās bibliotēkas digitālajā krājumā; 848. lpp.

Münster, Cosmographei || oder beschreibung aller lån/||der/ herrschafften/ fürnemsten || Sebastian stetten/geschichtẽ/gebreüchen/ hantierun||gen etc. zům offterẽ mal trefflich seer 1558. durch || Sebastianũ Munsterũ gebessert <...>. Basel: Henrichum Petri. VD16 M 6696. Vatkinsona bibliotēkas Hārtfordā eks. [sign. QUARTO G113 .M75 1558]; dccccxxxij. lpp. 
Münster, COSMO||GRAPHIAE || uniuersalis Lib.VI. in || quibus iuxta certioris fidei Sebastian scriptorum || traditionem describuntur, || Omnium habitabilis orbis partium situs, 1559. pro|| priaeque dotes. || ... Item omnium gentium mores, leges, religio ... || atque memorabilium in hunc usque an-|| num 1559.gestarum rerum Historia.|| Autore Sebast. Munstero. Basileae: apvd Henrichvm Petre. VD16 M 6718. Bavārijas Valsts bibliotēkas eks. [sign. Res/2 Geo.u. 55 m]. Digitālā versija: Münchener Digitalisierungszentrum; 789. lpp.

Münster, LA COS ||$M O G R A=||$ PHIE VNIVER | |SELLE, CONTENANT || la situation de Sebastian toutes les parties du monde, || auec leurs proprietez \& appartenances. || ... continuant 1560. iusques à nostre temps. || PAR SEBAST. MVNSTERE. Basel: de Henry Pierr. VD16 M 6709. Bāzeles Universitātes bibliotēkas eks. [sign. UBH Rc 223]; 888.-889. lpp.

Münster, Cosmographei || oder beschreibung aller län/||der/ herrschafften/ fürnemsten || Sebastian stetten/geschichten/gebreüchẽ/ hantierun||gen etc. Erstmals beschriben durch 1561. Se=|| bastianũ Munsterũ/ auch durch jhn selbst || gebessert <...>. Basel: durch Henrichum Petri. VD16 M 6697. Bavārijas Valsts bibliotēkas eks. [sign. Res/2 Geo.u. 56 m]. Digitālā versija: Münchener Digitalisierungszentrum; Mclxviij. lpp.

Münster, Cosmographey || oder beschreibung aller lån/||der/ herrschafften/ fürnemsten || Sebastian stetten/geschichten/gebreüchẽ ... || Erstmals beschriben durch Seba=||stianum 1564. Munsterum/ auch durch jn selbst || gebessert <...>. Basel: durch Henrichum Petri. VD16 M 6698. Bavārijas Valsts bibliotēkas eks. [sign. Hbks/E 6], Džona Kartera Brauna bibliotēkas Providensā eks. [sign. J564 .M948c ]. Digitālā versija: Münchener Digitalisierungszentrum; Mclxviij. lpp.

Münster, LA COS ||$M O G R A=||$ PHIE VNIVER || SELLE, CONTENANT || la situation Sebastian de toutes les parties du monde, || auec leurs proprietez \& appartenances. || ... PAR 1565. SEBAST. MVNSTERE. [Basel]: Henry Pierre. VD16 M 6710. Nacionālā muzeja Čartorisku bibliotēkas Krakovā eks. [sign. 2300 III Cim]. Digitālā versija: Biblioteka Cyfrowa Muzeum Narodowego w Krakowie digitālajā katalogā; 940.-941. lpp.

Münster, Cosmographey || oder beschreibung aller Lån/||der/ Herrschafften/ fürnew̃sten Sebastian Stetten/|| geschichten/gebreüchẽ/ handtierungen etc.|| Beschriben durch Sebastianum 1567. Munste $=||$ rũ/ auch durch jn selbst gebessert <...>. Basel: Officin Henricpetrina. VD16 M 6699. Freiburgas Alberta-Ludviga Universitātes bibliotēkas eks. [sign. J 4763,h], Bavārijas Valsts bibliotēkas eks. [sign. Res/2 Geo.u. 58], Džona Kartera Brauna bibliotēkas Providensā eks. [sign. J567 .M948c]. Digitālā versija: Münchener Digitalisierungszentrum; Mclxx. lpp.

Münster, LA COS ||$M O G R A=||$ PHIE VNIVER ||SELLE CONTENANT || la situation Sebastian de toutes les parties du monde, || ... continuant iusques à nostre temps.|| PAR 1568. SEBAST. MONSTERE. [Basel]: Henry Pierre. VD16 M 6711. Džona Kartera Brauna bibliotēkas Providensā eks. [sign. J568 .M948c], Vatkinsonas bibliotēkas Hārtfordā eks. [sign. QUARTO G113 .M75 1568]. Digitālā versija: Internet Archive; 940.-941. 1pp.

Münster, Cosmographey || oder beschreibung aller Lån/||der/ Herrschafften/ fürneĩsten Sebastian Stetten $/||$... Beschribẽ durch Sebastianum Munste $=||$ rũ / auch durch jn selbst gebessert 1569. <..>. Basel: Officin Henricpetrina. VD16 M 6700. Bavārijas Valsts bibliotēkas eks. [sign. Res/2 Geo.u. 59]. Digitālā versija: Münchener Digitalisierungszentrum; Mclx. lpp.

Münster, COSMOGRAPHIA || VNIVERSALE, || DISTRIBVTTA IN SEI LIBRI. || Sebastian NELLA QVALE, SECONDO CHE N'HANNO || PARLATO I PIV VERACI [1571]. SCRITTORI, || SON DESIGNATI <...>. Venetia: G. F. Thomasini. Francijas Nacionālās bibliotēkas eks. [sign. RES-G-68]; 848. lpp. 
Münster, Cosmographey || oder beschreibung aller Län-||der/ Herrschafften/ fürnem̃sten Sebastian Stetten/|| geschichten/gebreüchẽ... || Beschriben durch Sebastianum Munste =||rũ/ 1572. auch durch jn selbst gebessert <...>. Basel: Officin Henricpetrina. VD16 M 6701. Freiburgas Alberta-Ludviga Universitātes bibliotēkas eks. [sign. J 4763,i]. Digitālā versija: Freiburgas Alberta-Ludviga Universitātes bibliotēkas digitalajā kolekcijā; Mclx. lpp.

Münster, COSMOGRA||PHIAE VNIVERSA-||LIS LIB.VI. IN QVIBVS IVXTA || Sebastian CERTIORIS FIDEI SCRIPTORES ... || describuntur, || Omnium habitabilis Orbis 1572. partium situs propriaeque dotes. || Regionum Topographicae picturae. || ... Cunctarum Gentium mores, leges, religio, res gestae, \& mutationes usque ad an-|| num Christi M.D.LXXII. Item Regum ac Prlncipum genealogiae. | | AVTHORE SEBASTIANO MVNSTERO. Basileae: Officina Henricpetrina. VD16 M 6719. Bavāijas Valsts bibliotēkas eks. [sign. Hbks/E 7], Austrijas Nacionālās bibliotēkas eks. [sign. 47.Mm.55]. Digitālā versija: Münchener Digitalisierungszentrum; 939. 1pp.

Münster, Cosmographey || oder beschreibung aller Lån=||der/ Herrschafften/ fürnem̃sten Sebastian Stet $=||$ ten/ geschichten/gebreüchen ... || Beschrieben durch Sebastianum 1574. Munsterum/|| auch durch jhn selbst gebessert <...>. Basel: Officin Henricpetrina. VD16 M 6702. Bavārijas Valsts bibliotēkas eks. [sign. Hbks/E 7 m]. Digitālā versija: Münchener Digitalisierungszentrum; Mcxxiiij. lpp.

Münster, La Cosmographie vniverselle de tovt le monde <...>. Paris: Michel Sonnius. Sebastian Gentes Universitātes bibliotēkas eks. [sign. BIB.HIST.007397], Rēgensburgas 1575. Valsts bibliotēkas eks. [sign. 999/2Hist.pol.607(1]. Digitālā versija: Münchener Digitalisierungszentrum; 1623. lpp.

Münster, COSMOGRAPHIA || VNIVERSALE, || Nella quale secondo che n'hanno parlato Sebastian i piu || veraci Scrittori, son designati i siti di tutti gli paësi.|| ... Raccolta primo da 1575. diuersi autori per Sebastiano Munstero, et dapoi corretta et repur-| | gata [v.(Andrea Bosturino ... ||)], per gli Censori Ecclesiastici, et quei del Re Catholico nelli paesi || bassi, et per l'Inquisitore di Venetia. Colonia: Arnoldo Byrchmanno. VD16 M 6713. Bavārijas Valsts bibliotēkas eks. [sign. Res/2 Geo.u. 62]. Digitālā versija: Münchener Digitalisierungszentrum; 848. lpp.

Münster, Cosmographey.|| Oder beschreibung || Aller Lånder herrschafftenn || vnd fürnembsten Sebastian Stetten des gantzen || Erdbodens ... || Erstlich durch Herrn Sebastian Munster ... in 1578. $\quad$ sechs Bücher ver $=||$ fasset $/$ demnach ... durch jhn selbs gebesseret $<\ldots>$. Basel: Officin Henricpetrina. VD16 M 6703. Bavārijas Valsts bibliotēkas eks. [sign. Res/2 Geo.u. 63]. Digitālā versija: Münchener Digitalisierungszentrum; Mcxxiiij. lpp.

Münster, Cosmographey.|| Oder beschreibung || Aller Lånder herrschafftenn || vnd fürnemesten Sebastian Stetten des gantzen || Erdbodens ... || Erstlich durch Herrn Sebastian Munster ... in 1588. $\quad$ sechs $B \dot{e}=||$ cher verfasset: Demnach ... durch jhne selbs gebes $=||$ sert $<\ldots>$. Basel: Sebastianum Henricpetri. VD16 M 6704. Bavārijas Valsts bibliotēkas eks. [sign. Res/2 Geo.u. 64 t], Austrijas Nacionālās bibliotēkas eks. [sign. 47.Cc.1]. Digitālā versija: Münchener Digitalisierungszentrum; Mcxix. lpp.

Münster, Cosmographey.|| Oder beschreibung || Aller Lånder herrschafftenn || vnd Sebastian furrnemesten Stetten des gantzen || Erdbodens ... || Erstlich durch Herrn Sebastian 1592. Munster ... in sechs Bü=|| cher verfasset: Demnach ... durch jhne selbs gebes $=||$ sert $<\ldots>$. Basel: Sebastianum Henricpetri. VD16 M 6705. Bavārijas Valsts bibliotēkas eks. [sign. Hbks/E 9]. Digitālā versija: Münchener Digitalisierungszentrum; Mcxxj.-Mcxxij. lpp. 
Münster, Cosmographey:|| das ist/|| Beschreibung || Aller Lånder/ Herrschafften vnd Sebastian für||nemesten Stetten des gantzen Erdbodens/ sampt jhren || Gelegenheiten/ 1598. Eygenschafften/Religion/Gebräuchen/|| Geschichten vnd Handtierungen/etc. || Erstlich durch Herrn Sebastian Munster ... in sechs || Bücher verfasset $<\ldots .$. . Basel: Sebastianum Henricpetri. VD16 M 6706. Bāzeles Universitātes bibliotēkas eks. [sign. UBH Kartenslg Schw Ml 1], Bavārijas Valsts bibliotēkas eks. [sign. Rar. 831], Džona Kartera Brauna bibliotēkas Providensā eks. [sign. G113 .M75 1598]. Digitālā versija: Münchener Digitalisierungszentrum; Mcliiiji. lpp.

Münster, Cosmographey:|| das ist/|| Beschreibung || aller Länder/ Herrschafften/ und Sebastian für ||nemsten Stetten/ des gantzen Erdbodens: sampt ihren || Gelegenheiten/ 1614a. Eygenschafften/Religion/ Gebräuchen/ || Geschichten und Handtierungen/ [et]c $<\ldots>$. Basel: Henricpetri. VD17 23:635683K. Bavārijas Valsts bibliotēkas eks. [sign. 2 Gs 588]. Digitālā versija: Münchener Digitalisierungszentrum; 1310. lpp.

Münster, Cosmographey:|| das ist/|| Beschreibung || aller Länder/ Herrschafften/ und Sebastian für ||nemsten Stetten/ des gantzen Erdbodens: <...>. Otras titullapas nosaukums: 1614b. Cosmographia, || Das ist/|| Außführliche vnd eigentli=||che beschreibung aller Ländern, Herrschaff $=||$ ten vnd fürnembsten Stätten der gantzen Welt $<\ldots>$. Basel: Henricpetri. VD17 547:689033C. Saksijas-Anhaltes Universitātes un Valsts bibliotēkas eks. [sign. AB BB 2429], Freiburgas Alberta-Ludviga Universitātes bibliotēkas eks. [sign. J 4763,ti]; 1310. lpp.

Münster, Cosmographia, Das ist: Beschreibung der gantzen Welt : Darinnen Aller Monarchien Sebastian Keyserthumben/Königreichen/Fürstenthumben/ Graff-und Herrschafften/Länderen/ 1628. Stätten und Gemeinden <...>. Basel: Henricpetri. VD17 23:230709C. Marokas Karalistes Nacionālās bibliotēkas eks. (sign. R-F-128). Digitālā versija: Marokas Karalistes Nacionālās bibliotēkas katalogā; 1305. lpp.

\section{Literatūra}

Arbuzovs, Leonids. 1920. Latveešu tēvreize senos tekstos. Izglītības Ministrijas Mēnešraksts 10, 357-362.

Augstkalns, Alvils. 1930. Par vecajām tēvreizēm. Izglītības Ministrijas Mēnešraksts 1, 309-311.

Burmeister, Karl Heinz. Sebastian Münster: Versuch eines biographischen Gesamtbildes. 1969. Helbing \& Lichtenhahn.

Davies, Surekha. 2011.

America and Amerindians in Sebastian Münster's "Cosmographiae universalis libri VI” (1550). Renaissance Studies 25(3), 351-373.

de Kerimel, Guy et al. 2017. La prière du Notre Père: Un regard renouvelé. Cerf, Mame, Bayard.

Dini, Pietro Umberto. 2010. ALILETOESCVR: linguistica baltica delle origini. Teorie e contesti linguistici nel Cinquecento. Livorno: Books\&Company.

Draviņš, Kārlis. 1952.

Das Hasentötersche lettische Vaterunser. Studi Baltici 9, 211-230.

Draviņš, Kārlis. 1965.

Altlettische Schriften und Verfasser 1. Lund: Slaviska institutionen vid Lunds universitet.

Draviņš, Kārlis. 1972.

Par latvǐsu tāvreizi. Dzeive 113, 26. lpp.

Freidhof, Gerd. 1988.

Kozmograffia Cžeská: Praha 1554. Teil 1. München: Verlag Otto Sagner. 
Galić, Anđelka, Antonia

Došen. 2017.

Günther, Otto. 1913.

Hantzsch, Victor. 1898.

Hinze, Friedhelm. 1976.

Hodgen, Margaret T. 1954.

Horn, Werner. 1950.

Klekere, Ināra. 2020.

(b. a.). 1974

Lindgren, Uta. 2002.

Mclean, Matthew Adam. 2005.

Mclean, Matthew Adam. 2007.

Meringer, Rudolf. 1895.

Meurer, Peter H. 1993.

Ozols, Arturs. 1965.

Petrella, Giancarlo. 2006.

Pokrotniece, Kornēlija. 2012.

Priesner, Claus. 1997.

Robinson, C. N., Leyland John. 1964.

Ruland, Harold L. 1962a.
Sebastian Münster Cosmographia as the renaissance mirror of the world, Geoadria 22(1), 65-104.

Hans Hasentödter: ein preussischer Poet des 16. Jahrhunderts. In Zeitschrift des Westpreussischen Geschichtsvereins 55, 1-48

Sebastian Munster: Leben, Werk, Wissenschaftliche Bedeutung. Leipzig: B. G. Teubner.

Hat Matthãus Prätorius (um 1635-1707) ein „Kurisches“ Vaterunser gekannt?. Acta Baltico-Slavica 10, 235-264.

Sebastian Muenster (1489-1552): A Sixteenth-Century Ethnographer. Osiris 11, 504-529.

Sebastian Münster's Map of Prussia and the Variants of It. Imago Mundi 7, 67-73.

Attēlu izcelsme un funkcijas Livonijas aprakstā. Sebastiāna Minstera „Kosmogrāfijas“ 16. gadsimta izdevumos. In Ineta Kivleg (red.). Grāmata. Zīme. Krāsa. Rīga: LU Akadēmiskais apgāds, 114-123.

Atrasts sens latviešu tēvreizes teksts, Laiks 4 (12. janvāris), 5. lpp.

Kosmographie, Landkarten und Vermessungslehre bei Sebastian Münster. In Gabriele Mendelssohn (red.). Sebastian Münster (1488-1552): Universalgelehrter und Weinfachmann aus Ingelheim. Katalog zur Ausstellung im Alten Rathaus NiederIngelheim, 12. Oktober bis 10. November 2002, Beiträge zur Ingelheimer Geschichte 46(1). Ingelheim: Historischer Verein Ingelheim, 27-39.

The Cosmographia of Sebastian Münster. PhD Thesis. University of St Andrews.

The Cosmographia of Sebastian Münster: Describing the World in the Reformation. Ashgate Publishing.

Ein altes lettisches Vaterunser. Archiv für slavische Philologie 17, Berlin: Weidmannsche Buchhandlung.

Der neue Kartensatz von 1588 in der Kosmographie Sebastian Münsters, Cartographica Helvetica 7, 11-20.

Veclatviešu rakstu valoda. Rīga: Liesma.

Libri proibiti e Inquisizione a Milano nel secondo Cinquecento. Un esemplare espurgato de La Cosmografia di Sebastian Münster. La Bibliofilía 108(3), 251-279.

Grēki un parādi - pamest vai piedot? (Ieskats latviešu senajās tēvreizēs). Baltistica VIII priedas, 111-122.

Sebastian Münster. In Otto Stolberg-Wernigerode. Neue deutsche Biographie. Bd. 18. Berlin: Duncker\&Humblot, 539-541.

The literature of the Sea. From the Origins to Hakluyt, in A.W. Ward, A. R. Waller. The Cambridge History of English Literature IV: Prose and poetry, Cambridge: The University press.

A Survey of the Double-Page Maps in Thirty-Five Editions of the "Comographia Universalis" 1544-1628 of Sebastian Münster and in His Editions of Ptolemy's "Geographia" 1540 1552. Imago Mundi 16, 84-97. 
Ruland, Harold L. 1962b. The Rare and Enigmatic 1615 Title-Page accompanying Sebastian Münster's 1614 Cosmographey. Imago Mundi 16, 161-162.

Schirren, Carl. 1858.

Das Vaterunser des Heruler, als Plagiat erwiesen. Bulletin histórico-philologi de l' Acad. Im. 16, Melanges russes 3, 659-674.

Sēja, Pēteris. 1925.

Vēl kāds latviešu tēvreizes teksts. Izglìtības Ministrijas Mēnešraksts $11,285$.

Švābe, Arveds. 1936 . Latviešu zemnieks 16. gs. historiogrāfijā. Senatne un Māksla 4, 38-49.

van Putten, Jasper. 2017. Networked Nation: Mapping German Cities in Sebastian Münster's 'Cosmographia', Leiden, Boston: Brill.

Vögelin, Salomon. 1882. Sebastian Münsters Cosmographey. Basler Jahbuch, 110-152.

Vanags, Pēteris. 1996.

$\mathrm{VD} 16=$

1586. gada Katehisma tekstu izcelsme. Tēvreize, Svētā kristība, Debesu atslēgas jeb Grēku piedošana, Svētais vakarēdiens. Res Balticae 2, 85-98.

Das Verzeichnis der im deutschen Sprachbereich erschienenen Drucke des 16. Jahrhunderts. Izmantota elektroniskā versija: http://www.vd16.de

$\mathrm{VD} 17=$

Das Verzeichnis der im deutschen Sprachraum erschienenen Drucke des 17. Jahrhunderts. Izmantota elektroniskā versija: www.vd17.de

Wessel, Günther. 2004. Von einem, der daheim blieb, die Welt zu entdecken: die Cosmographia des Sebastian Münster, oder, Wie man sich vor 500 Jahren die Welt vorstellte. Frankfurt, New York: Campus Verlag.

Zēvers, Jānis. 1929.

Vecas tēvreizes latviešu valodā. Izglìtības Ministrijas Mēnešraksts $12,512-518$.

Ernesta Kazakeinaite

Baltistikos katedra

Baltijos kalbu ir kultūrų institutas

Filologijos fakultetas

Vilniaus universitetas

Universiteto g. 5, LT-01131, Vilnius, Lietuva

ernesta.kazakenaite@flf.vu.lt 
Pielikums. 32 MK izdevumos esošo latviešu tēvreižu paralēlais korpuss (salīdzināšanai sniegtas arī pirmās trīs zināmās ar roku rakstītās tēvreizes $(\mathrm{a}-\mathrm{c})$, kas ņemtas no http://senie.korpuss.lv).

\begin{tabular}{|c|c|c|c|c|c|c|c|c|c|}
\hline \multirow[b]{2}{*}{$\mathrm{Nr}$. } & \multirow[b]{2}{*}{ Datums } & \multirow[b]{2}{*}{ Avots } & \multicolumn{7}{|c|}{ Vārdi } \\
\hline & & & 1 & 2 & 3 & 4 & 5 & 6 & 7 \\
\hline a & $\sim 1507$ & Ghisbert & Teweß & müß & $\mathrm{ka}$ & tw & efe & exkan & debbefy $\beta$ \\
\hline b & $\sim 1520$ & Bruno & Tewes & mufs & \multicolumn{2}{|c|}{ kastu } & es & excã & debbefifs. \\
\hline c & $\sim 1520$ & Grunau & Nosfen & Thewes & Cur & thu & es & & delbas \\
\hline 1 & 1550 & $\mathbf{M K}_{\mathrm{v}}$ & Tàbes & mus & kas & tu & es & eckfchan & debbeffis/ \\
\hline 2 & 1553 & $\mathbf{M K}_{\mathrm{v}}$ & Tåbes & mus & kas & tu & es & eckfchan & debbeffis/ \\
\hline 3 & 1556 & $\mathbf{M K}_{\mathrm{v}}$ & Tåbes & mus & kas & tu & es & eckfchan & debbeffis/ \\
\hline 4 & 1558 & $\mathbf{M K}_{\mathrm{v}}$ & Tåbes & mus & kas & tu & es & eckfchan & debbeffis/ \\
\hline 5 & 1561 & $\mathbf{M K}_{\mathrm{v}}$ & Tåbes & mus & kas & tu & es & eckfchan & debbeffis/ \\
\hline 6 & 1564 & $\mathbf{M K}_{\mathrm{v}}$ & Tåbes & mus & kas & tu & es & eckfchan & debbeffis/ \\
\hline 7 & 1567 & $\mathbf{M K}_{\mathrm{v}}$ & Tåbes & mus & kas & tu & es & eckfchan & debbeffis/ \\
\hline 8 & 1569 & $\mathbf{M K}_{\mathrm{v}}$ & Tåbes & mus & kas & tu & es & eckfchan & debeffis/ \\
\hline 9 & 1572 & $\mathbf{M K}_{\mathrm{v}}$ & Tåbes & mus & kas & tu & es & eckfchan & debeffis/ \\
\hline 10 & 1574 & $\mathbf{M K}_{\mathrm{v}}$ & Tåbes & mus & kas & tu & es & eckfchan & debeffis/ \\
\hline 11 & 1578 & $\mathbf{M K}_{\mathrm{v}}$ & Tåbes & mus & kas & tu & es & eckfchan & debeffis/ \\
\hline 12 & 1588 & $\mathbf{M K}_{\mathrm{v}}$ & Tåbes & mus & kas & tu & es & eckfchan & debbeffis/ \\
\hline 13 & 1592 & $\mathbf{M K}_{\mathrm{v}}$ & Tåbes & mus & kas & tu & es & eckfchan & debbeffis/ \\
\hline 14 & 1598 & $\mathbf{M K}_{\mathrm{v}}$ & Tåbes & mus & kas & tu & es & eckfchkan & debbeffis/ \\
\hline 15 & $1614 a$ & $\mathbf{M K}_{\mathrm{v}}$ & Tåbes & mus & kas & tu & es & eckfchkan & debbeffis/ \\
\hline 16 & $1614 \mathrm{~b}$ & $\mathbf{M K}_{\mathrm{v}}$ & Tåbes & mus & kas & tu & es & eckfchkan & debbeffis/ \\
\hline 17 & 1628 & $\mathbf{M K}_{\mathrm{v}}$ & Tåbes & mus & kas & tu & es & eckfchkand & lebbeffis/ \\
\hline 18 & 1550 & $\mathbf{M K}_{\mathrm{lat}}$ & Tábes & mus & kas & tu & es & eckfchkan & debbeffis, \\
\hline 19 & $1552 \mathrm{a}$ & $\mathbf{M K}_{\text {lat }}$ & Tæbes & mus & kas & tu & es & eckfchkan & debbefsis, \\
\hline 20 & $1552 \mathrm{~b}$ & $\mathbf{M K}_{\text {lat }}$ & Tåbes & mus & kas & tu & es & eckfchkan & debbeffis, \\
\hline 21 & 1554 & $\mathbf{M K}_{\text {lat }}$ & Tębes & mus & kas & tu & es & eckfchkan & debbefsis, \\
\hline 22 & 1559 & $\mathbf{M K}_{\text {lat }}$ & Tæbes & musk & & tu & es & eckfchkan & debbefsis, \\
\hline 23 & 1572 & $\mathbf{M K}_{\text {lat }}$ & Tæbes & mus & kas & tu & es & ekfchkan & debbefsis, \\
\hline 24 & 1552 & $\mathbf{M K}_{\mathrm{fr}}$ & Mus & tabes & kas & tu & es' & eckfchkan & debbeffis, \\
\hline 25 & 1556 & $\mathbf{M K}_{\mathrm{fr}}$ & Mus & tabes & kas & tu & es, & eckfckan & debbefsis, \\
\hline 26 & 1560 & $\mathbf{M K}_{\mathrm{fr}}$ & Mus & tabes & kas & tu & es, & eckfckan & debbefsis, \\
\hline 27 & 1565 & $\mathbf{M K}_{\mathrm{fr}}$ & Mus & tabes & kas & tu & es, & eckfckan & debbefsis, \\
\hline 28 & 1568 & $\mathbf{M K}_{\mathrm{fr}}$ & Mus & tabes & kas & tu & es, & eckfckan & debbefsis, \\
\hline 29 & 1575 & $\mathbf{M K}_{\mathrm{fr}}$ & Mus & tabes, & kas & tu & es, & eckfckan & debbeffis, \\
\hline 30 & 1558 & $M_{\text {it }}$ & Tębes & mus & kas & tu & es & eckfchkã & debbefsis, \\
\hline 31 & $\sim 1571$ & $\mathbf{M K}_{\mathrm{it}}$ & Tębes & mus & kas & tu & es & eckfchkã & debbefsis, \\
\hline 32 & 1575 & $\mathbf{M K}_{\mathrm{it}}$ & Tębes & mus & kas & tu & es & eckfchkã & debbefsis, \\
\hline
\end{tabular}




\section{Pielikuma apzīmējumi}

|| - rindas beigas grāmatā; * nav skaidrs, iespējams lasīt arī citādi;

— šãdi iekrāsoti vārdi atšḳiras no pirmā attiecīgas valodas publicējuma;

38. vārdā $r$ burts kursīvā, jo tas salikts citā šriftā, ko nebija iespējams atspoguḷot, sk.:

\section{patzeduetë/}

\begin{tabular}{|c|c|c|c|c|c|c|c|c|}
\hline \multirow[b]{2}{*}{ Nr. } & \multicolumn{8}{|c|}{ Vārdi } \\
\hline & 8 & $8 \mathrm{a}$ & 9 & 10 & 11 & 12 & 13 & 14 \\
\hline a & fwetyt & bws & tow $\beta$ & ward $\beta$ & ennak & $\operatorname{mum} \beta$ & tow & walfcyby \\
\hline b & Swetytz & & touwes & Waardt & Enacks & mums & touws & wallftibfs \\
\hline c & Zweÿtz & gifcher & thowes & wardes & Penag & munis & Tholbe & müftlaftilbi \\
\hline 1 & Schwetit3 & & tows & waart3/. & enack || & mums & tows & walftibe \\
\hline 2 & Schwetit3 & & tows & waart3/ & enack | ! & mums & tows & walftibe \\
\hline 3 & Schwetit3 & & tows & waart3/ & enack | | & mums & tows & walftibe \\
\hline 4 & Schwetit3 & & tows & waart3/ & enack || & mums & tows & walftibe \\
\hline 5 & Schwetit3 & & tows & waart3/ & enack | | & mums & tows & walftibe \\
\hline 6 & Schwetit3 & & tows & waart3/ & enack & mums & tows $\mid 1$ & walftibe \\
\hline 7 & Schwetit3 & & tous & wart3/ & enack & mums & tows || & walftibe \\
\hline 8 & Schwetit3 & & tous & wart3/ & enack & mums & tows $\mid 1$ & walftibe/ \\
\hline 9 & Schwetit3 & & tous & wart3/ & enack & mums & tows || & walftibe/ \\
\hline 10 & Schwetit3 & & tous & wartz/ & enack & mums & tows || & walftibe/ \\
\hline 11 & Schwetit3 & & tous & wart3/ & enack & mums & tows || & walftibe/ \\
\hline 12 & Schwetit3 & & tows & waart3/ & enack & mums & tows 11 & walftibe/ \\
\hline 13 & Schwetit3 & & tows & waart3/ & enack & mums & tows || & walftibe/ \\
\hline 14 & Schwetit3 & & tows & waart3/ & enack & mums & tows $\mid 1$ & walftibe/ \\
\hline 15 & Schwetit3 & & tows & waart3/ & enack & mums & tows || & walftibe/ \\
\hline 16 & Schwetit3 & & tows & waart3/ & enack & mums & tows || & walftibe/ \\
\hline 17 & Schwetit3 & & tows & waart3/ & enack & mums & tows || & walftibe/ \\
\hline 18 & fchwetitz & & tows & waartz, & Enack & mums & tows || & walftibe, \\
\hline 19 & fchuuetitz & & touus & uuaartz, & Enack & moms & touus || & uualftibe, \\
\hline 20 & fchwetitz & & tows & waartz, & Enack & mums & tows $\mid 1$ & walftibe, \\
\hline 21 & fchuuetitz & & touus & uuaartz, & Enack & moms & touus | | & uualftibe, \\
\hline 22 & fchuuetitz & & touus & uuaartz, & enack & moms & touus | I & uualftibe, \\
\hline 23 & fchuuetitz & & touus & uuaartz, & Enack & mũs & touus || & uualftibe, \\
\hline 24 & fchwetitz & & tows & waartz, & Enack & mums & tows $\mid 1$ & walftibe, \\
\hline 25 & fchuuetitz & & touus & uuaartz, & Enack & mums & touus | | & vualftibe, \\
\hline 26 & fchuuetitz & & tous & uuaartz, & Enack & mums & touus || & vualftibe, \\
\hline 27 & fchuuetitz & & tous & uuaartz, & Enack & mums & touus | I & uualftibe, \\
\hline 28 & fchuuetitz & & tous & uuaartz, & Enack & mums & touus | I & uualftibe, \\
\hline 29 & fchuuetitz & & tous & uuaarts: & Enack & mums & touus || & uualftibe: \\
\hline 30 & fchuuetitz & & touus & uuaartz, & Enack & moms & touus | | & uualftibe, \\
\hline 31 & fchuuetitz & & touus & uuaartz, & Enack & moms & touus | ! & uualftibe, \\
\hline 32 & fchuuetitz & & touus & uuaartz, & Enack & moms & touus || & uualftibe, \\
\hline
\end{tabular}




\begin{tabular}{|c|c|c|c|c|c|c|c|c|c|c|}
\hline \multirow[b]{2}{*}{ Nr. } & \multirow[b]{2}{*}{ Datums } & \multirow[b]{2}{*}{ Avots } & \multicolumn{8}{|c|}{ Vârdi } \\
\hline & & & \multirow{2}{*}{15} & 16 & 17 & 18 & 19 & 20 & 21 & \multirow[t]{2}{*}{$21 \mathrm{a}$} \\
\hline a & $\sim 1507$ & Ghisbert & & praaz & $\mathrm{bw} \beta$ & $\mathrm{ka}$ & exkan & debby $\beta$ & Vnnd & \\
\hline $\mathrm{b}$ & $\sim 1520$ & Bruno & Touws & \multicolumn{2}{|c|}{ pratzbus } & $\mathrm{ka}$ & eckfchan & debbes-sis. & $\mathrm{Ta}$ & \multirow{2}{*}{$\begin{array}{l}\text { arrifan } \\
\text { Sÿmmes }\end{array}$} \\
\hline c & $\sim 1520$ & Grunau & Tolpes & pratres & \multicolumn{2}{|c|}{ Girkade } & & delbesfime & tade & \\
\hline 1 & 1550 & $\mathbf{M K _ { \mathrm { v } }}$ & tows & praats & bus & $\mathrm{ka}$ & eckfchkan & Debbes/ & ta & \\
\hline 2 & 1553 & $\mathbf{M K}_{\mathbf{v}}$ & tows & praats & bus & $\mathrm{ka}$ & eckfchkan & Debbes/ & ta & \\
\hline 3 & 1556 & $\mathbf{M K}_{\mathbf{v}}$ & tows & praats & bus & $\mathrm{ka}$ & eckfchkan & Debbes/ & ta & \\
\hline 4 & 1558 & $\mathbf{M K}_{\mathrm{v}}$ & tows & praats & bus & $\mathrm{ka}$ & eckfchkan & Debbes/ & ta & \\
\hline 5 & 1561 & $\mathbf{M K}_{\mathrm{v}}$ & tows & praats & bus & $\mathrm{ka}$ & eckfchkan & Debbes/ & ta & \\
\hline 6 & 1564 & $\mathbf{M K}_{\mathbf{v}}$ & tows & praats & bus & \multicolumn{2}{|c|}{ kaeckfchkan* } & Debbes/ & ta & \\
\hline 7 & 1567 & $\mathbf{M K}_{\mathrm{v}}$ & tows & prauts & bus & $\mathrm{ka}$ & eckfchkan & Debbes/ & ta & \\
\hline 8 & 1569 & $\mathbf{M K}_{\mathbf{v}}$ & tows & prauts & bus & \multicolumn{2}{|c|}{ kaeckfchkan } & Debbes & ta & \\
\hline 9 & 1572 & $\mathbf{M K}_{\mathrm{v}}$ & tows & prauts & bus & \multicolumn{2}{|c|}{ kaeekfchan } & Debbes & ta & \\
\hline 10 & 1574 & $\mathbf{M K}_{\mathrm{v}}$ & tows & prauts & bus & \multicolumn{2}{|c|}{ kaeckfchan } & Debbes & ta & \\
\hline 11 & 1578 & $\mathbf{M K}_{\mathrm{v}}$ & tows & prauts & bus & \multicolumn{2}{|c|}{ kaeckfchan } & Debbes & ta & \\
\hline 12 & 1588 & $\mathbf{M K}_{\mathrm{v}}$ & tows & praats & bus & $\mathrm{ka}$ & eckfchkan & Debbes/ & ta & \\
\hline 13 & 1592 & $\mathbf{M K}_{\mathrm{v}}$ & tows & praats & bus & $\mathrm{ka}$ & eckfchkan & Debbes/ & ta & \\
\hline 14 & 1598 & $\mathbf{M K}_{\mathrm{v}}$ & tows & praat3 & bus & eka & eckfchkan & Debbes/ & ta & \\
\hline 15 & $1614 a$ & $\mathbf{M K}_{\mathbf{v}}$ & tows & praat3 & bus & eka & eckfchkan & Debbes/ & ta & \\
\hline 16 & $1614 \mathrm{~b}$ & $\mathbf{M K}_{\mathrm{v}}$ & tows & praat3 & bus & eka & eckfchkan & Debbes/ & ta & \\
\hline 17 & 1628 & $\mathbf{M K}_{\mathrm{v}}$ & tows & praat3 & bus & eka & \multicolumn{2}{|c|}{ eckfchkannDebbes/* } & ta & \\
\hline 18 & 1550 & $\mathbf{M K}$ lat & tows & praats & bus & $\mathrm{ka}$ & ekfchkan & debbes & ta & \\
\hline 19 & $1552 \mathrm{a}$ & $\mathbf{M K} \mathbf{K}_{\text {lat }}$ & touus & praats & bus & $\mathrm{ka}$ & ekfchkan & debbes & ta & \\
\hline 20 & $1552 b$ & $\mathbf{M K} \mathbf{K}_{\mathrm{lat}}$ & tows & praats & bus & $\mathrm{ka}$ & ekfchkan & debbes & ta & \\
\hline 21 & 1554 & $\mathbf{M K}_{\text {lat }}$ & touus & praats & bus & $\mathrm{ka}$ & ekfchkan & debbes & ta & \\
\hline 22 & 1559 & $\mathbf{M K}$ lat & touus & praats & bus & $\mathrm{ka}$ & ekfchkan & debbes & ta & \\
\hline 23 & 1572 & $\mathbf{M K} \mathbf{K}_{\text {lat }}$ & touus & praats & bus & $\mathrm{ka}$ & ekfehkan & debbes & ta & \\
\hline 24 & 1552 & $\mathbf{M K}_{\mathrm{fr}}$ & tows & praatz & bus & $\mathrm{ka}$ & ekfchkan & debbes & ta & \\
\hline 25 & 1556 & $\mathbf{M K}_{\mathrm{fr}}$ & touus & praatz & bus & $\mathrm{ka}$ & ekfchkan & debbes & ta & \\
\hline 26 & 1560 & $\mathbf{M K}_{\mathrm{fr}}$ & touus & praatz & bus & $\mathrm{ka}$ & ekfchkan & debbes & ta & \\
\hline 27 & 1565 & $\mathbf{M K}_{\mathrm{fr}}$ & tous & praatz & bus & eka & kfchkan & debbes & ta & \\
\hline 28 & 1568 & $\mathbf{M K}_{\mathrm{fr}}$ & tous & praatz & bus & eka & kfchkan & debbes & ta & \\
\hline 29 & 1575 & $\mathbf{M K}_{\mathrm{fr}}$ & tous & praatz & bus & eka & kfchkan & debbes, & ta & \\
\hline 30 & 1558 & $\mathbf{M K}_{\mathrm{it}}$ & touus & praats & bus & $\mathrm{ka}$ & ekfchkã & debbes & ta & \\
\hline 31 & $\sim 1571$ & $\mathbf{M K}_{\mathrm{it}}$ & touus & praats & bus & $\mathrm{ka}$ & ekfchkã & debbes & ta & \\
\hline 32 & 1575 & $\mathbf{M K}_{\mathrm{it}}$ & touus & praats & bus & $\mathrm{ka}$ & ekfchkã & debbes & ta & \\
\hline
\end{tabular}




\begin{tabular}{|c|c|c|c|c|c|c|c|c|}
\hline \multirow[b]{2}{*}{$\mathrm{Nr}$. } & \multicolumn{8}{|c|}{ Vārdi } \\
\hline & 22 & 23 & 24 & 25 & 26 & 27 & 28 & 29 \\
\hline a & exkann & femeß & muße & dynyze & mayfe & & & \\
\hline b & wurfan & femmes & Mufse & denifske & mayfe & duth & hmufs & fchodee \\
\hline c & Semmes & Worsünÿ & dodi & mommÿs & Annosse & igdemas & maÿse, & unde \\
\hline 1 & wurfan | | & femmes. & Muffe & denifche & Màyfe & důth & $\operatorname{müm} \beta$ & fchodeen/ \\
\hline 2 & wurfan | | & femmes. & Muffe & denifche & Màyfe & düth & $\operatorname{müm} \beta$ & fchodeen/ \\
\hline 3 & wurfan | | & femmes. & Muffe & denifche & Måyfe & düth & $\operatorname{müm} \beta$ & fchodeen/ \\
\hline 4 & wurfan || & femmes. & Muffe & denifche & Måyfe & düth & mümß & fchodeen/ \\
\hline 5 & wurfan |I & femmes. & Muffe & denifche & Måyfe & düth & $m \ddot{m} \beta$ & fchodeen/ \\
\hline 6 & wurfan & femmes. & Muffe & denifche || & Måyfe & düth & $\operatorname{müm} \beta$ & fchoden/ \\
\hline 7 & wurfan & femmes. & Muffe & denifche|| & Måyfe & düth & $\operatorname{müm} \beta$ & fchoden / \\
\hline 8 & wurfan & femes. & Muffe & denifche |! & Màyfe & $\mathrm{d}[\ddot{\mathrm{u}}] \mathrm{th}^{*}$ & $\operatorname{müm} \beta$ & fchoden/ \\
\hline 9 & wurfan & feñes. & Muffe & denifche || & Måyfe & düth & mümß & fchodẽ/ \\
\hline 10 & wurfan & femmes. & Muffe & denifche|| & Măyfe & düth & $\operatorname{mum} \beta$ & fchoden/ \\
\hline 11 & wurfan & femmes. & Muffe & denifche $\mid !$ & Màyfe & düth & $\operatorname{mum} \beta$ & fchoden/ \\
\hline 12 & wurfan & femmes. & Muffe & denifche | ! & Màyfe & düth & mums & fchodeen/ \\
\hline 13 & wurfan & femmes. & Muffe & denifche || & Måyfe & düth & mums & fchodeen/ \\
\hline 14 & wurfan & femmes. & Muffe & denifche || & & duth & mums & fchodeen/ \\
\hline 15 & wurfan & femmes. & Muffe & denifche | | & Màyfe & duth & mums & fchodeen/ \\
\hline 16 & wurfan & femmes. & Muffe & denifche|| & Măyfe & duth & mums & fchodeen/ \\
\hline 17 & wurfan & femmes. & Muffe & denifche || & Måyfe & duth* & mums & fchodeen/ \\
\hline 18 & wurfan & femmes, & Muffe & denifche & måyfe|| & duth & mums & fchodeen, \\
\hline 19 & uuurfan & femmes, & Muffe & denifche & mæyfe|| & duth & mums & fchodeen, \\
\hline 20 & wurfan & femmes, & Muffe & denifche & måyfe|| & duth & mums & fchodeen, \\
\hline 21 & uuurfan & femmes, & Muffe & denifche & megfe|| & duth & mums & fchodeen, \\
\hline 22 & uuurfan & fẽmes, & muffe* & denifche & męyfe|| & duth & mums & fchodeen, \\
\hline 23 & uuurfan & femmes, & Muffe & denifche $\mid !$ & mæyfe & duth & mums & fchodeen, \\
\hline 24 & wurfan & femmes, & Muffe & denifche & måife|| & duth & mums & fchodeen, \\
\hline 25 & vurfan & femmes, & Muffe & denifche & maife|I & duth & mums & fchodeen, \\
\hline 26 & vurfan & femmes, & Muffe & denifche & maife|| & duth & mums & fchodeen, \\
\hline 27 & uurfan & femmes, & Muffe & denifche & maife | I & duth & mums & fchodéen, \\
\hline 28 & uurfan & femmes, & Muffe & denifche & maife |I & duth & mums & fchodéen, \\
\hline 29 & uurfan & femmes: & Muffe & denifche & maife |I & duth & mums & fchodeen: \\
\hline 30 & uuurfan & femmes, & Muffe & denifche & megfe || & duth & mums & fchodeẽ, \\
\hline 31 & uuurfan & femmes, & Muffe & denifche & megyfe|l & duth & mums & fchodeẽ, \\
\hline 32 & uuurfan & femmes, & Muffe & denifche & meyfe|| & duth & mums & fchodeẽ, \\
\hline
\end{tabular}




\begin{tabular}{|c|c|c|c|c|c|c|c|c|c|}
\hline \multirow[b]{2}{*}{ Nr. } & \multirow[b]{2}{*}{ Datums } & \multirow[b]{2}{*}{ Avots } & \multicolumn{7}{|c|}{ Vārdi } \\
\hline & & & $29 a$ & 30 & 31 & 32 & 33 & 34 & 35 \\
\hline a & $\sim 1507$ & Ghisbert & & & & & & & \\
\hline b & $\sim 1520$ & Bruno & & Pammete & mums & mufo & grecks & & ames \\
\hline c & $\sim 1520$ & Grunau & Gä̈tkas & Pammes & mumÿs & nusfe & nozegimi & Caden & mes \\
\hline 1 & 1550 & $\mathbf{M K}_{\mathrm{v}}$ & & pammate & můms || & muße & gråke & $\mathrm{ka}$ & $\mathrm{me} \beta$ \\
\hline 2 & 1553 & $\mathbf{M K}_{\mathrm{v}}$ & & pammate & můms|| & muße & grăke & $\mathrm{ka}$ & $\mathrm{me} \beta$ \\
\hline 3 & 1556 & $\mathbf{M K}_{\mathrm{v}}$ & & pammate & můms || & muße & grăke & $\mathrm{ka}$ & meß \\
\hline 4 & 1558 & $\mathbf{M K}_{\mathrm{v}}$ & & pammate & můms || & muffe & gråke & $\mathrm{ka}$ & meß \\
\hline 5 & 1561 & $\mathbf{M K}_{\mathrm{v}}$ & & pammate & můms || & muffe & gråke & $\mathrm{ka}$ & $\mathrm{me} \beta$ \\
\hline 6 & 1564 & $\mathbf{M K}_{\mathrm{v}}$ & & pammate & můms & muffe & gråke & $\mathrm{ka}$ & $\mathrm{me} \beta$ \\
\hline 7 & 1567 & $\mathbf{M K}_{\mathrm{v}}$ & & pammate & můms & muffe & gräke & $\mathrm{ka}$ & meß \\
\hline 8 & 1569 & $\mathbf{M K}_{\mathrm{v}}$ & & pammate & müms & muffe & grăke & $\mathrm{ka}$ & mes \\
\hline 9 & 1572 & $\mathbf{M K}_{\mathrm{v}}$ & & pammate & můms & muffe & grăke & $\mathrm{ka}$ & mes \\
\hline 10 & 1574 & $\mathbf{M K}_{\mathrm{v}}$ & & pammate & můms & muffe & gråke & ka & ames \\
\hline 11 & 1578 & $\mathrm{MK}_{\mathrm{v}}$ & & pammate & můms & muffe & gråke & $\mathrm{ka}$ & mes \\
\hline 12 & 1588 & $\mathbf{M K}_{\mathrm{v}}$ & & pammate & mums & muffe & gräke & $\mathrm{ka}$ & mes \\
\hline 13 & 1592 & $\mathbf{M K}_{\mathrm{v}}$ & & pammate & mums & muffe & gråke & $\mathrm{ka}$ & mes \\
\hline 14 & 1598 & $\mathbf{M K}_{\mathrm{v}}$ & & pammate & mums & muffe & gräke & $\mathrm{ka}$ & mes \\
\hline 15 & $1614 a$ & $\mathbf{M K}_{\mathrm{v}}$ & & pammate & mums & muffe & gråke & $\mathrm{ka}$ & mes \\
\hline 16 & $1614 b$ & $\mathbf{M K}_{\mathrm{v}}$ & & pammate & mums & muffe & grăke & $\mathrm{ka}$ & mes \\
\hline 17 & 1628 & $\mathbf{M K}_{\mathrm{v}}$ & & pammate & mums & muffe & grăke & $\mathrm{ka}$ & mes \\
\hline 18 & 1550 & $\mathbf{M K}_{\mathrm{lat}}$ & & pammate & mums & muffe & gråke & $\mathrm{ka}$ & mefs \\
\hline 19 & $1552 \mathrm{a}$ & $\mathbf{M K}_{\text {lat }}$ & & pammate & mums & muffe & græke & $\mathrm{ka}$ & mefis \\
\hline 20 & $1552 \mathrm{~b}$ & $\mathbf{M K}_{\text {lat }}$ & & pammate & mums & muffe & gråke & $\mathrm{ka}$ & mefs \\
\hline 21 & 1554 & $\mathbf{M K}_{\text {lat }}$ & & pammate & mums & muffe & græke & $\mathrm{ka}$ & mefis \\
\hline 22 & 1559 & $\mathbf{M K}_{\text {lat }}$ & & pammate & mums & muffe & gręke & $\mathrm{ka}$ & mefis \\
\hline 23 & 1572 & $\mathbf{M K}_{\text {lat }}$ & & pammate & mums & muffe & græke & $\mathrm{ka}$ & mefis \\
\hline 24 & 1552 & $\mathbf{M K}_{\mathrm{fr}}$ & & pammate & mums & muffe & gräke & $\mathrm{ka}$ & mefs \\
\hline 25 & 1556 & $\mathbf{M K}_{\mathrm{fr}}$ & & pammate & emums* & muffe & grake & $\mathrm{ka}$ & mefs \\
\hline 26 & 1560 & $\mathrm{MK}_{\mathrm{fr}}$ & & pammate & mums & muffe & grake & $\mathrm{ka}$ & mefs \\
\hline 27 & 1565 & $\mathbf{M K}_{\mathrm{fr}}$ & & pammate & mums & muffe & grake & $\mathrm{ka}$ & mefs \\
\hline 28 & 1568 & $\mathbf{M K}_{\mathrm{fr}}$ & & pammate & mums & muffe & grake & $\mathrm{ka}$ & mefs \\
\hline 29 & 1575 & $\mathbf{M K}_{\mathrm{fr}}$ & & pammate & mums & muffe & grake, & $\mathrm{ka}$ & mefs \\
\hline 30 & 1558 & $\mathbf{M K}_{\mathrm{it}}$ & & pãmate & mums & muffe & græke & $\mathrm{ka}$ & mefis \\
\hline 31 & $\sim 1571$ & $\mathbf{M K}_{\mathrm{it}}$ & & pãmate & mums & muffe & græke & $\mathrm{ka}$ & mefis \\
\hline 32 & 1575 & $\mathbf{M K}_{\mathrm{it}}$ & & pãmate & mums & muffe & græke & $\mathrm{ka}$ & mefis \\
\hline
\end{tabular}




\begin{tabular}{|c|c|c|c|c|c|c|c|c|c|}
\hline \multirow[b]{2}{*}{ Nr. } & \multicolumn{9}{|c|}{ Vārdi } \\
\hline & 36 & 37 & 38 & 39 & 40 & 41 & 42 & 43 & 44 \\
\hline \multicolumn{10}{|l|}{$\mathrm{a}$} \\
\hline b & pammeten & mufse & parraduckems & \multicolumn{3}{|c|}{ Neekwedfemums } & lounam & badeklems & AEth \\
\hline c & Pametam & mu-sen & Prettaune kans & \multicolumn{2}{|r|}{ newede } & munis & lawnan & Padoman & \\
\hline 1 & pammat & muße & parradueken/ & $\mathrm{Ne}$ & wedde & mums | & louna & badeckle/ & pett \\
\hline 2 & pammat & $\operatorname{muße}$ & parradueken/ & $\mathrm{Ne}$ & wedde & mums || & louna & badeckle/ & pett \\
\hline 3 & pammat & muße & parradueken/ & $\mathrm{Ne}$ & wedde & mums || & louna & badeckle/ & pett \\
\hline 4 & pammat & muffe & parradueken/ & $\mathrm{Ne}$ & wedde & mums || & louna & badeckle/ & pett \\
\hline 5 & pammat & muffe & parradueken/ & $\mathrm{Ne}$ & wedde & mums || & louna & badeckle/ & pett \\
\hline 6 & pammat & muffe || & parraduekẽ / & $\mathrm{Ne}$ & wedde & mums & louna & badeckle/ & pett \\
\hline 7 & pammat & muffe || & parreduekẽ/ & $\mathrm{Ne}$ & wedde & mums & louna & badeckle/ & pett \\
\hline 8 & pammat & muffe | I & parreduekẽ/ & $\mathrm{Ne}$ & wedde & mums & louna & badeckle/ & pett \\
\hline 9 & pammat & muffe | I & parrednekẽ/ & $\mathrm{Ne}$ & wedde & mums & louna & badeckle/ & pett \\
\hline 10 & pammat & muffe || & parredueken/ & $\mathrm{Ne}$ & wedde & mums & louna & badeckle/ & pett \\
\hline 11 & pammat & muffe | I & parredueken/ & $\mathrm{Ne}$ & wedde & mums & louna & badeckle/ & pett \\
\hline 12 & pammat & muffe || & parradueken/ & $\mathrm{Ne}$ & wedde & mums & louna & badeckle/ & pett \\
\hline 13 & pammat & muffe|| & parradueken/ & $\mathrm{Ne}$ & wedde & mums & louna & badeckle/ & pett \\
\hline 14 & pammart & muffe || & parradueken/ & $\mathrm{Ne}$ & ewedde & mums & jouna & badeckle/ & pett \\
\hline 15 & pammart & muffe |I & parradueken/ & $\mathrm{Ne}$ & ewedde & mums & jouna & badeckle/ & pett \\
\hline 16 & pammart & muffe || & parradueken/ & $\mathrm{Ne}$ & ewedde & mums & jouna & badeckle/ & pett \\
\hline 17 & pammart & muffe |I & parzadueken/ & $\mathrm{Ne}$ & ewedde & mums & jouna & badeckle/ & pett \\
\hline 18 & pammat & muffe & parradueken || & $\mathrm{Ne}$ & ewedde & mums & louna & badekle & pett \\
\hline 19 & pammat & muffe & parradueken || & $\mathrm{Ne}$ & euuedde & mums & louna & badekle & pett \\
\hline 20 & pammat & muffe & parradueken || & $\mathrm{Ne}$ & ewedde & mums & louna & badekle & pett \\
\hline 21 & pammat & muffe & parradueken || & $\mathrm{Ne}$ & euuedde & mums & louna & badeckle & epett \\
\hline 22 & pammat & muffe & parraduekẽ || & ne & euuedde & mums & louna & badeckle & epett \\
\hline 23 & pammat & muffe |! & parradueken, & $\mathrm{Ne}$ & euuedde & mums & louna & badekle & pett \\
\hline 24 & pammat & muffe & parradueken || & $\mathrm{Ne}$ & ewedde & mums & louna & badeckle & pett \\
\hline 25 & pammat & muffe & parradueken || & $\mathrm{Ne}$ & euuedde & mums & louna & badeckle & pett \\
\hline 26 & pāmatt & muffe & parradueken || & $\mathrm{Ne}$ & euuedde & mums & Iouna & badeckle & pett \\
\hline 27 & pammart & muffe & parraducken || & $\mathrm{Ne}$ & euuedde & mums & Iouua & badeckle & pett \\
\hline 28 & pammart & muffe & parraducken || & $\mathrm{Ne}$ & euuedde & mums & Iouua & badeckle & pett \\
\hline 29 & pammart & muffe & parraducken | | & $\mathrm{Ne}$ & euuedde & mums & Iouua & badeckle : & pett \\
\hline 30 & pammat & muffe* & parradueken || & $\mathrm{Ne}$ & euuedde & mums & louna & badeckle & epett \\
\hline 31 & pammat & muffe* & parradueken || & $\mathrm{Ne}$ & euuedde & mums & louna & badeckle & epett \\
\hline 32 & pammat & muffe* & parradueken || & $\mathrm{Ne}$ & euuedde & mums & louna & badeckle & epett \\
\hline
\end{tabular}




\begin{tabular}{|c|c|c|c|c|c|c|c|c|c|}
\hline \multirow[b]{2}{*}{ Nr. } & \multirow[b]{2}{*}{ Datums } & \multirow[b]{2}{*}{ Avots } & \multicolumn{7}{|c|}{ Vārdi } \\
\hline & & & 45 & 46 & 47 & 48 & 49 & $49 a$ & 50 \\
\hline a & $\sim 1507$ & Ghisbert & & & & & & & \\
\hline b & $\sim 1520$ & Bruno & pefti & mums & no & wyfsem & lounem. & & \\
\hline c & $\sim 1520$ & Grunau & Swalbadi & munis & nowusfe & & Loyne & Jesus & Amen \\
\hline 1 & 1550 & $\mathbf{M K}_{\mathrm{v}}$ & paffarga & mums & $\mathrm{nu}$ & wüffe & loune & & Amen. \\
\hline 2 & 1553 & $\mathbf{M K}_{\mathrm{v}}$ & paffarga & mums & nu & wüffe & loune & & Amen. \\
\hline 3 & 1556 & $\mathbf{M K}_{\mathrm{v}}$ & paffarga & mums & $\mathrm{nu}$ & wüffe & loune & & Amen. \\
\hline 4 & 1558 & $\mathbf{M K}_{\mathrm{v}}$ & paffarga & mums & nu & wüffe & loune & & Amen. \\
\hline 5 & 1561 & $\mathbf{M K}_{\mathrm{v}}$ & paffarga & mums & nu & wüffe & loune & & Amen. \\
\hline 6 & 1564 & $\mathbf{M K}_{\mathrm{v}}$ & pafferga & mums & $\mathrm{nu}$ & wüffe & loune. & & \\
\hline 7 & 1567 & $\mathbf{M K}_{\mathrm{v}}$ & pafferga & mums & nu & wüffe & loune. & & \\
\hline 8 & 1569 & $\mathbf{M K}_{\mathrm{v}}$ & pafferga & mũs & nu & wüffe & loune. & & \\
\hline 9 & 1572 & $\mathbf{M K}_{\mathrm{v}}$ & pafferga & mũs & nu & wüffe & loune. & & \\
\hline 10 & 1574 & $\mathbf{M K}_{\mathrm{v}}$ & pafferga & mums & nu & wüffe & loune. & & \\
\hline 11 & 1578 & $\mathbf{M K}_{\mathrm{v}}$ & pafferga & mums & nu & wüffe & loune. & & \\
\hline 12 & 1588 & $\mathbf{M K}_{\mathrm{v}}$ & paffarga & mums & nu & wüffe & loune. & & \\
\hline 13 & 1592 & $\mathbf{M K}_{\mathrm{v}}$ & paffarga & mums & nu & wüffe & loune. & & \\
\hline 14 & 1598 & $\mathbf{M K}_{\mathrm{v}}$ & paffarga & mums & nu & wuffe & joune. & & \\
\hline 15 & $1614 a$ & $\mathbf{M K}_{\mathrm{v}}$ & paffarga & mums & nu & wuffe & joune. & & \\
\hline 16 & $1614 b$ & $\mathbf{M K}_{\mathrm{v}}$ & paffarga & mums & nu & wuffe & joune. & & \\
\hline 17 & 1628 & $\mathbf{M K}_{\mathrm{v}}$ & paffarga & mums & nu & wuffe & joune. & & \\
\hline 18 & 1550 & $\mathbf{M K}_{\text {lat }}$ & paffarga & mums & nu & wuffe & loune & & Amen. \\
\hline 19 & $1552 a$ & $\mathbf{M K}$ lat & paffarga & mums & $\mathrm{nu}$ & uuuffe & loune & & Amen. \\
\hline 20 & $1552 b$ & $\mathbf{M K}_{\text {lat }}$ & paffarga & mums & nu & wuffe & loune & & Amen. \\
\hline 21 & 1554 & $\mathbf{M K}_{\text {lat }}$ & paffarga & mums & nu & uuuffe & loune & & Amen. \\
\hline 22 & 1559 & $\mathbf{M K}$ lat & paffarga* & mums & nu & uuffe & loune. & & Amen. \\
\hline 23 & 1572 & $\mathbf{M K}$ lat & paffarga & mums & nu & uuuffe & loune, || & & Amen. \\
\hline 24 & 1552 & $\mathbf{M K}_{\mathrm{fr}}$ & paffarga & mums & nu & wuffe & loune. & & \\
\hline 25 & 1556 & $\mathbf{M K}_{\mathrm{fr}}$ & paffarga & mums & nu & uuuffe & loune. & & \\
\hline 26 & 1560 & $\mathrm{MK}_{\mathrm{fr}}$ & paffarga & mums & nu & uuuffe & Ioune. & & \\
\hline 27 & 1565 & $\mathbf{M K}_{\mathrm{fr}}$ & paffarga & mums & nu & uuuffe & louue & & \\
\hline 28 & 1568 & $\mathbf{M K}_{\mathrm{fr}}$ & paffarga & mums & $\mathrm{nu}$ & uuuffe & louue & & \\
\hline 29 & 1575 & $\mathbf{M K}_{\mathrm{fr}}$ & paffarga & mums & $\mathrm{nu}$ & uuuffe & Iouue. & & \\
\hline 30 & 1558 & $\mathrm{MK}_{\mathrm{it}}$ & paffarga & mums & nu & uuuffe & loune & & Amen. \\
\hline 31 & $\sim 1571$ & $\mathbf{M K}_{\mathrm{it}}$ & paffarga & mums & nu & uuuffe & loune & & Amen. \\
\hline 32 & 1575 & $\mathbf{M K}_{\mathrm{it}}$ & paffarga & mums & nu & uuuffe & loune & & Amen. \\
\hline
\end{tabular}




\section{SUMMARY \\ Pasargā no visa jauna ('Deliver us from anything new'), or The Lord's Prayer in Latvian in the Editions of the Cosmography by Sebastian Münster}

\section{Ernesta KAZAKĖNAITÉ}

The article analyzes different versions of The Lord's Prayer in Latvian, which were published in the editions of the Cosmography by Sebastian Münster (hereafter MC). Although the issue of the number of editions is highly problematic, after reviewing the accessible literature and examining the original copies, a conclusion was made that there were about $37 \mathrm{MC}$ editions. In 32 of them, the Latvian prayer was found. The Latvian text appeared for the first time in the edition of 1550, and was repeated in later German editions and translations into Latin, French and Italian up until 1628. Although the basis of the prayer encountered in all of the editions is the same, the actual texts almost always have some differences, thus, in total, 23 variants of the Latvian prayer in MC are attested. The main differences are usually in orthography and appear to be errors of rewriting or compilation, e.g., pasargā no visa jauna meaning 'deliver us from anything new'. Instead of the word launa 'evil', jauna 'new' was used when in the printed text the lower case $l$ letter was misinterpreted as upper case $I$.

After examining the variants, a quite natural tendency was noted: with almost each new publication since the very first one there are more and more textual discrepancies. The typology of writing errors in the Latvian prayers and changes to the prayer shows that part of them are inherent to the MC editions in a specific language. Three traditions become apparent: 1) German, 2) Latin (and the Italian that is based on it), as well as 3) French. A conclusion was made that the origin of these traditions is more likely coincidental, determined by extralinguistic factors, since Münster himself prepared the first publications for these languages and did not know any Latvian. Nevertheless, there were links between different text traditions, since the Latvian prayer in the 1598 German edition looks edited in accordance with the text found in the French translation.

The most important conclusion of this study is that not only was MC in general constantly changed and supplemented, but also the Latvian prayer included in it was not constant. Therefore, when talking about Johann Hasentödter's prayer in MC as a possible source for other publications of The Lord's Prayer in Latvian, one should keep in mind the abundance of variants that can help to identify a more precise source. 